\title{
Lithostratigraphy, Structure, Geological History, Economic Geology and Paleontology of Mari Bugti Hills and Surrounding Areas of Balochistan, South Punjab and North Sindh (Pakistan)
}

\author{
Muhammad Sadiq Malkani1 ${ }^{*}$, Yousaf Haroon² \\ ${ }^{1}$ Geological Survey of Pakistan, Muzaffarabad, Pakistan \\ ${ }^{2}$ Geological Survey of Pakistan, Islamabad, Pakistan \\ Email: *malkanims@yahoo.com
}

How to cite this paper: Malkani, M.S. and Haroon, Y. (2022) Lithostratigraphy, Structure, Geological History, Economic Geology and Paleontology of Mari Bugti Hills and Surrounding Areas of Balochistan, South Punjab and North Sindh (Pakistan). Open Journal of Geology, 12, 13-56. https://doi.org/10.4236/ojg.2022.121002

Received: October 24, 2021

Accepted: January 9, 2022

Published: January 12, 2022

Copyright $\odot 2022$ by author(s) and Scientific Research Publishing Inc. This work is licensed under the Creative Commons Attribution International License (CC BY 4.0).

http://creativecommons.org/licenses/by/4.0/ Open Access

\begin{abstract}
Mari Bugti hills and surroundings belong to Sulaiman basin (fragment of Gondwana) lies under the territory of Balochistan, South Punjab and North Sindh (Pakistan) but luckily have diverse marine and terrestrial sediments varying in age from Triassic to Recent, petroleum and a large number of mineral resources especially huge gypsum and cement resources, numerous suitable anticlinal structures and world-famous paleontology. The large-sized poripuchian titanosaurs, theropods, mesoeucrocodiles, pterosaur, bird and snake were reported from the latest Cretaceous Vitakri Formation, and largest terrestrial mammals and eucrocodiles were reported from the Oligocene Chitarwata Formation and other mammals were also reported from Late $\mathrm{Pa}$ leogene and Neogene terrestrial deposits. Previously part of this area was not mapped due to remoteness and security problems but recently the mapping of these areas was started. Further, the structural and geological maps of previously omitted parts are added here. After performing the multidisciplinary field investigations by senior author, the corresponding results were obtained. The main objective of this work is to focus on the lithostratigraphic deposits, structure, geological history, economic geology and paleontology of the Mari Bugti Hills and surrounding areas.
\end{abstract}

\section{Keywords}

Stratigraphy, Structures, Faults, Anticlines, Synclines, Geological History, Economic Geology, Paleontology, Mesozoic, Cenozoic, Mari Bugti Hills, 
Balochistan, South Punjab, North Sindh, Sulaiman Arc, Pakistan

\section{Introduction}

Pakistan has both Gondwanan and Laurasian fragments and parts and also Tethyan blocks. Hindukush-Karakoram belongs to Laurasia. Balochistan and Kohistan magmatic arcs belong to Tethys. Indus basin belongs to Gondwana. Indus basin is contacted with Balochistan basin via western Indus suture (UthalWadLasbela-Nal Khuzdar-western Samugli Quetta, western Ghazaband-KuchlakZiarat Cross-Gwal-Khanozai-Muslimbagh-Qila Saifullah-Zhob-western Waziristan-Mohmand) and Kohistan-Ladakh magmatic arc via northern Indus suture (Mohmand-Swat-Besham-Chilas-Haramosh-Astore-Kargal). The Indus basin is further subdivided into uppermost/northernmost Indus (Khyber-Hazara-Neelam basin), Upper Indus/North Indus (Kohat-Potwar-Kotli basin), middle Indus/central Indus (Sulaiman basin), and Lower Indus/South Indus (Kirthar basin) basins. The study areas lie in the middle Indus/ Sulaiman basin, under the territory of Dera Bugti, Kohlu, Sibi, Loralai, Musakhel and Barkhan districts of Balochistan Province, Dera Ghazi Khan and Rajan Pur districts of South Punjab, Daharki, Ghotki, Pano Aqil, Khairpur, Kashmore, Kandhkot, Thul and Jacobabad of North Sindh. Mari Bugti hills and surroundings are located on the southern part of Sulaiman basin. This area is also called Sulaiman arc. The northern and northwestern parts of Mari Bugti hills are accessible from Duki and Mekhtar town of Loralai district, Kingri town of Musakhel district, Rakhni town of Barkhan district. The western part is accessible from Harnai of Ziarat district, from Narwal area of Quetta district, Mach and Abegum area of Kachi (Bolan) district. The southwestern part of study area is accessible from Talli, Lahri and surrounding areas of Sibi district and southeastern part is mostly plain and easily accessible from different routes in North Sindh and Dera Bugti district of Balochistan, and eastern part is accessible from Jampur and Rajanpur (via Lundi Saidan near Harrand) and Dera Ghazi Khan district (via Fort Munro and Rakhni). Previously most of parts of Mari Bugti hills and surroundings were ignored for geological mapping due to remoteness and security problems. Recently some areas were mapped. Here the lithostratigraphy, structures, geological history, economic geology and paleontology of Mari Bugti hills especially previously omitted parts are presented.

\section{Materials and Methods}

The materials belong to compiled data from previous work especially mentioned in references and also new field materials collected by present senior author during numerous field seasons regarding the lithology, stratigraphy, structure, economic geology and paleontology. The methods applied here are many disciplines of purely geological procedure and description. 


\section{Results and Discussion}

Here the results and discussion are represented as the lithostratigraphy, structure, geological history, economic geology and paleontology of Mari Bugti hills and surrounding areas (Figure 1) of Balochistan, South Punjab and North

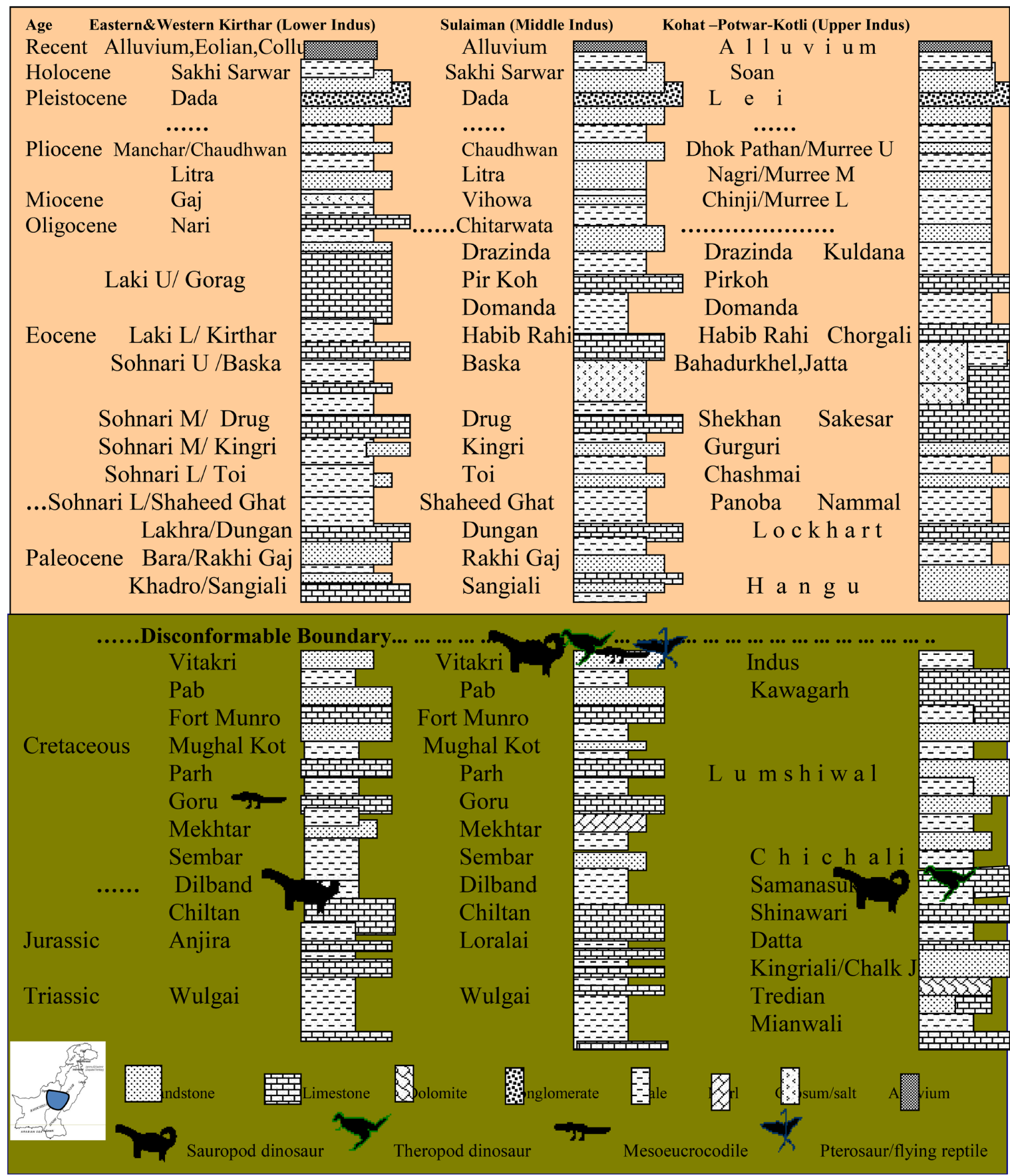

Figure 1. Revised Stratigraphic Correlation of South/Lower Indus (Eastern and Western Kirthar), Middle Indus (Sulaiman) and North/Upper Indus (Kohat-Potwar-Kotli) basins of Pakistan. Abbreviations for Mirpur-Kotli-Muzaffarabad sub basin (south Kashmir) and part of Potwar; L-Lower, M-Middle, U-Upper. Blue subrectangle in Map of Pakistan on lower right corner represents study area (Mari Bugti hills and surroundings) of Sulaiman arc of Sulaiman Foldbelt, Balochistan, South Punjab and North Sindh, Pakistan. 
Sindh, Pakistan.

\subsection{Lithostratigraphy of Mari Bugti Hills and Surrounding Areas, Balochistan and South Punjab, Pakistan}

Khairpur-Jacobabad-Bolan is a major anticlinorium which acts as boundary between middle Indus (Sulaiman) basin and south Indus (Kirthar) basin. Sedimentary rocks comprising of shale, sandstone, limestone, siltstone, conglomerate and marl ranging in age from Triassic to Recent in both basins (Figure 1) are divided in to many formations [1]-[10]. These stratigraphic formations are also reported in different geological maps of different areas like Dera Bugti (39 G/4) [11], Kohlu (39 G/5) [12], Vitakri (39 G/6) [13], Sham (Sardar Wadera Shero Bugti Sham)-Phailawagh (39 G/7) [14], Beaker (39 G/10) [15], Fort Munro (39 G/13) [16], Loralai (39 B/11) [17], Shabozai (39 B/15) [18], Kotkai-Tor Thana (39 F/3) [19], Hosri (39 F/4) [20], Mekhtar (39 F/7) [21], Chamalang (39 F/8) [22], Bahlol (39 F/12) [23], Musa Khel Bazar (39 F/13) [24], Kingri (39 F/15) [25], Rakhni (39 F/16) [26], Toi Nala-Chitarwata (39 I/4) [27] and others. These lithostratigraphic formations are revised and updated [6] [7] [8] [28] [29] [30]. The Mesozoic and Cenozoic sediments (formations and groups) are separated by Cretaceous-Paleogene (K-Pg) boundary or Cretaceous-Tertiary (K-T) boundary (Figure 2) (Figure 3) (Figure 4) which is briefly being described here.

Sulaiman Group: The Triassic-Jurassic Sulaiman Group [6] [10] includes the Wulgai, Loralai, Chiltan and Dilband formations which are exposed in the Western Indus Suture belt and western Sulaiman basin. Sulaiman Group was proposed in 2009 [6] and formally described in 2010 [7]. Wulgai Formation is included here in the Sulaiman Group due to following reasons like the Gwal and Spingwar formations have same lithology and age horizon like Wulgai Formation. In the Sulaiman basin and western Indus suture the three formations (Wulgai, Spingwar, Gwal formations) have same lithology, same horizon and age. Among these the one distinguished Wulgai formation included in the Sulaiman Group and other two formations (Spingwar and Gwal formations) may be used as synonym. Further many areas of western Indus suture were visited by one of us (MSM) and the erodeable shale (forms valleys) with some marl and limestone of Wulgai Formation was found and consistent in the western Sulaiman basin and also western Indus suture. This lithology is followed by thin to medium bedded limestone alternated by shale and marl of Loralai Formation which is further followed by thick bedded to massive limestone of Chiltan Formation. These oldest rocks exposures are located in the Khuzdar, Shirinab, Ghazaband, Gwal, Muslimbagh, Qila Saifullah and Zhob areas. Western Indus suture is a belt indicating suture of Indo-Pakistan subcontinental plate (in the east) and Tethys part of Arabian and Asian plate (on the west). The western Indus suture started Uthal to Bela to Nal Khuzdar to West of Quetta to Ghazaband to Kuchlak to Khanozai to Muslimbagh to Qila Saifullah to Zhob to western Waziristan to Mohmand. Then northern Indus suture started from Mohmand to Swat to Besham to Chilas to Haramosh to Astore to Kargal. The ophiolitic thrusting is the 
major feature of these two suture belts. The trilobite [31] [32] existence in the lower part of Sulaiman Group in the Chotok Kil area of Moola Zahri range

(Khuzdar district) extends the age of Sulaiman Group upto Permo-Triassic

\section{E G E N D}

Qa Recent and Sub-Recent Alluvium

Tv Vihowa Group and Sakhi Sarwar Group

Tk Kahan Group

Tg Chamalang Group

Tr Sangiali Group

Kf $\quad$ Fort Munro Group

Kp Parh Group

Js Sulaiman Group

C Coal seam

\section{SYMBOLS}

Contact

$\mathrm{K}-\mathrm{Pg}(\mathrm{K}-\mathrm{T})$ Boundary

Road

Rud/Nala/Stream

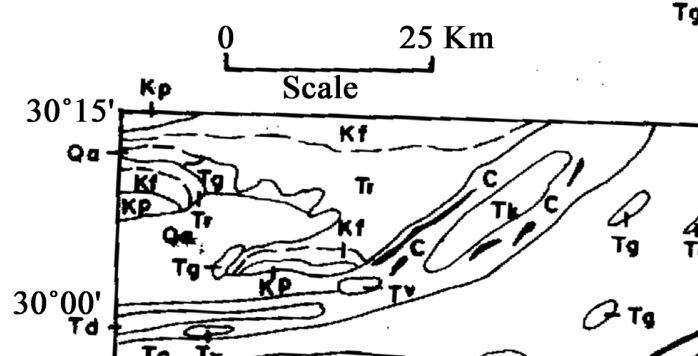

$70^{\circ} 45^{\prime}$

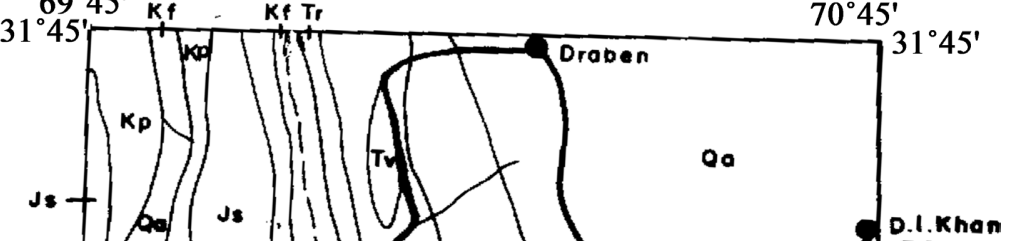

$30 \mathrm{~km}$.
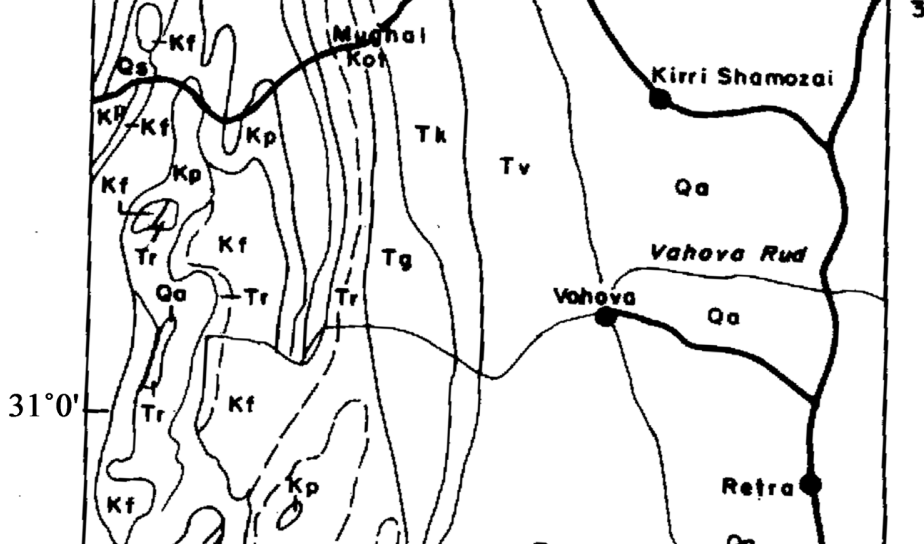

$y^{k f}$
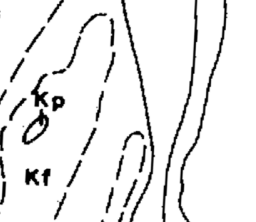

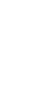




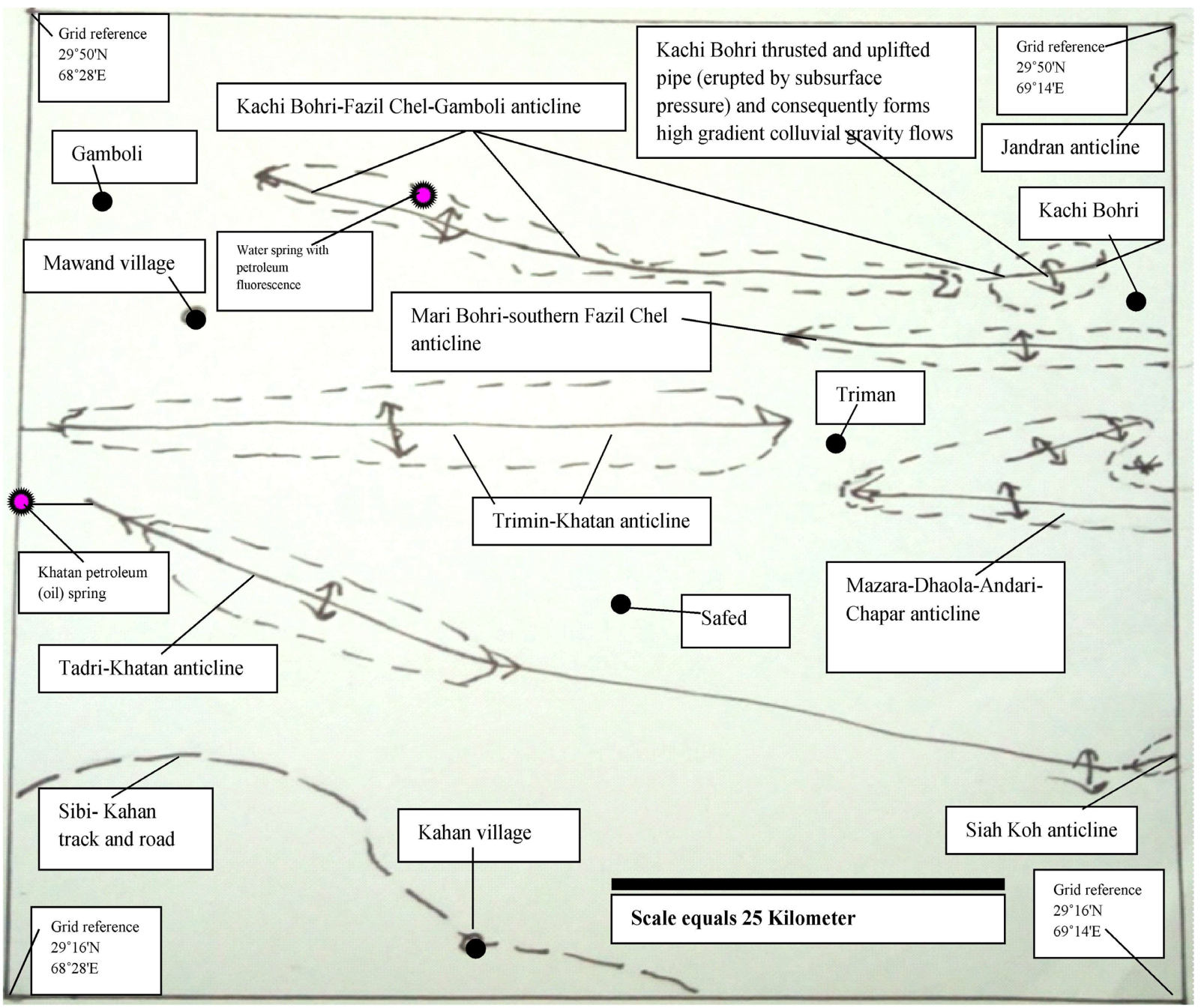

\section{LEGEND}

Pre K-Pg (Cretaceous-Paleogene) Transition or Pre KTB (Cretaceous-Tertiary Boundary) rocks: These rocks are bounded in the core of dashed loops. These older rocks include Triassic-Jurassic Sulaiman Group, Lower Cretaceous Parh Group and Upper Cretaceous Fort Munro Group.

Post K-Pg boundary sediments or Post KTB (Cretaceous-Tertiary Boundary) sediments: These rocks found outside the dashed loops. These younger rocks include Paleocene Sangiali Group, Early Eocene Chamalang Group, late Early-Late Eocene Kahan Group, Oligocene-Miocene Vihowa Group, Pleistocene-Holocene Sakhi Sarwar Group, Subrecent \& Recent alluvium, colluvium and eolian deposits.

K-Pg (Cretaceous-Paleogene) Transition or KTB (Cretaceous-Tertiary Boundary): It is represented by contact of latest Cretaceous strata like grey muddy sandstone or maroon to red muds of Vitakri Formation or sandstone beds of Pab sandstone (where Vitakri Formation is missing) with the Earliest Paleocene strata like green shale/mud of Early Paleocene Sangiali Formation or sandstone of Rakhi Gaj Formation (where Sangiali is missing).

\section{SYMBOLS}

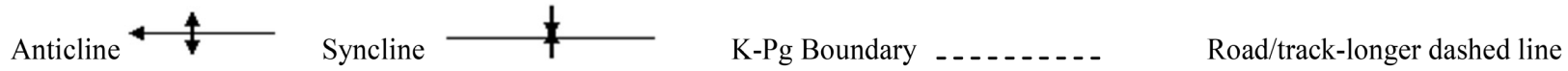

Figure 3. Geological Map showing K-Pg boundary, pre K-Pg rocks and post K-Pg sediments of Gamboli, south Pazha, Mawand, Khatan, Kahan, Safed, western Nisau, Triman, Makhmar, Fazil Chel, Kachi Bohri and surrounding areas of Mari hills (Mari tribes), Balochistan Province, Pakistan. 


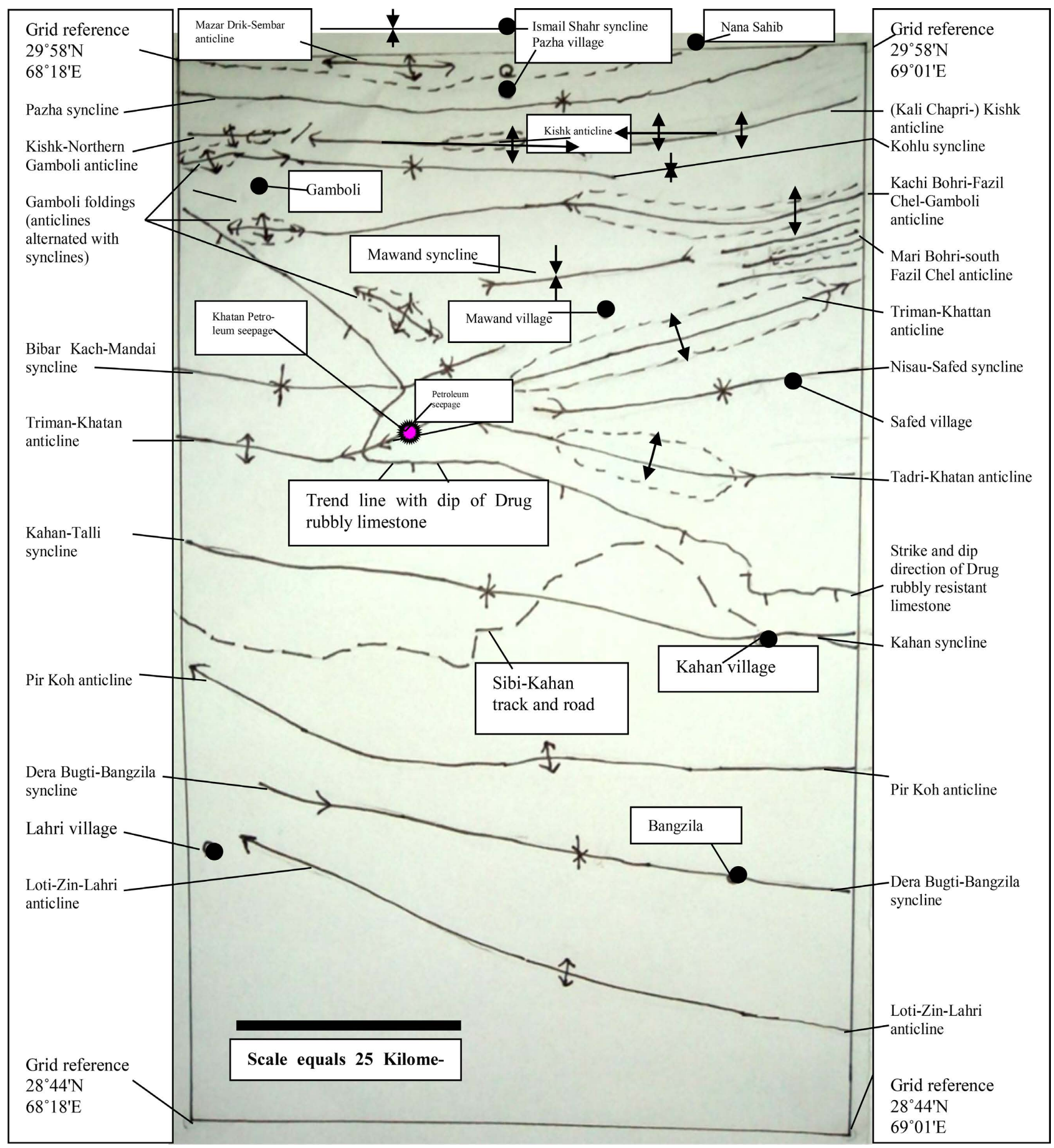

Figure 4. Structural foldings (anticlines and synclines) of western part of Dera Bugti district, and Pazha, Gamboli, Mawand, Kahan, Safed, Triman, Makhmar, Fazil Chel areas of Kohlu districts, Balochistan Province, Pakistan. For legend and symbols, see Figure 3.

boundary.

Wulgai Formation: Wulgai name is after the Wulgai village [33] near Muslimbagh and 16 kilometer $(\mathrm{km})$ toward north from Khanozai town. Here it consists of lower shale unit, middle limestone, marl and shale unit and upper shale dominant unit. Its lower contact is not exposed while upper contact with Loralai 
Formation is transitional. Its age is Triassic.

Loralai Formation: The Loralai member of Shirinab Formation was named by [33] and upgraded as Loralai Formation by [1]. It represents mainly thin to medium bedded grey limestone with some grey shale and marl. It is mostly peak forming especially in the vicinity of Loralai, Mekhtar, Gadebar, Tor Thana, Anambar, etc. In these areas, the Chiltan Limestone is not developed. Its lower contact with Wulgai Formation and upper contact with Chiltan Limestone is conformable. Where the Chiltan Formation is missing, its upper contact with Sembar Formation is disconformable and represented by Jurassic-Cretaceous (J-K) boundary. This J-K boundary is well exposed in the northwest of Loralai area. Its age is lower to middle Jurassic.

Chiltan Limestone: The Chiltan Limestone was introduced after the Chiltan Koh south west of Quetta [1]. It consists of grey, massive and thick bedded biohermal or reefal limestone with negligible marl and shale. Its lower contact with Loralai Formation is conformable and transitional while upper contact with Sembar formation is disconformable and at places conformable. Its age is Middle to Late Jurassic.

Dilband Formation: Dilband Formation was introduced by [34] and designated three members like lower Jarositic clay member (light grey to brown), middle ironstone member (reddish), and upper green glauconitic shale member. Dilband Formation (syn; Mazar Drik Formation) existed upto 20m yellow to red coloured weather belt of marl and shale on the contact of Loralai and Sembar formations, exposed in the Loralai and surrounding areas. The conspicuous reddish brown and maroon muds alternated with marly silty beds (significant for paleontological collections on $\mathrm{J} / \mathrm{K}$ boundary) found in the north of Tor Thana village (just at the southern base of major ridge. It represents lacustrine and terrestrial depositions of $\mathrm{J} / \mathrm{K}$ transitions.

Parh Group: The Early Cretaceous Parh Group [1] [6] [7] [10] includes the Sembar, Mekhtar, Goru and Parh formations. All formations of Parh Group are exposed in the northern and western part of study area like Musa Khel Bazaar, Mekhtar, Loralai, Mazar Drik and Sembar type localities (north of Pazha), Sanjawi, Ziarat, Sor Range-Deghari and Quetta surroundings. While its upper formations are also dispersely (as disseminated) exposed in the core of anticlines like Fort Munro anticline (at Shadiani section), Mazara (at Hanki section between Kachar and Barkhan valleys), Triman, Tadri and Gamboli anticlines and Hosri and Alif Mir Jan thrusts.

Sembar Formation: The term Sembar Formation was proposed by [33]. It consists of mainly shale with minor siltstone and marly beds. The thickness of this formation is estimated $400-800 \mathrm{~m}$. Tor Ghundi pegmatite [35] located at latitude $30^{\circ} 18^{\prime} 04^{\prime \prime} \mathrm{N}$ and longitude $68^{\circ} 48^{\prime} 51^{\prime \prime} \mathrm{E}$ and intruded in the Sembar shale in the east of Loralai town, south of Shabozai village and southwest of Kasa syncline. This pegmatite consists of feldspar and subordinate mica crystal (3 - 5 $\mathrm{cm}$ ). It is a circular pipe or plug type (about $1 \mathrm{~km}$ in diameter) surrounded dolerite type igneous rocks and then by Parh limestone and Sembar Shale of Parh 
Group. This pegmatite is scarce in quartz. There is another showing about $2 \mathrm{~km}$ in the east from this main plug/pipe in Sembar shale. The reference [36] reported it as Tor Ghar nepheline synites. The lower contact of Sembar Shale with Dilband ferruginous beds, Chiltan limestones (where Dilband Formation is missing) and Loralai Formation (where Dilband and Chiltan Formation is missing) are transitional, disconformable to conformable. The upper contact of Sembar shale with Mekhtar Formation is sharp and conformable found in the western part of Sulaiman and Kirthar basins and with Goru Formation is transitional and conformable where Mekhtar Formation is not developed especially in the western part of Sulaiman and Kirthar basins. Recently dinosaurs Brohisaurus kirthari titanosauriform fossils found from Sun Chaku (Karkh area) and Charoh (Zidi area) localities of Khuzdar district (Kirthar range) [37]. Its age is Early Cretaceous.

Mekhtar Formation: Three members of Sembar formation as lower shale, middle Mekhtar sandstone and upper shale members were established [7]. The Mekhtar sandstone member was upgraded as Mekhtar Formation [9]. Its type locality (latitude $30^{\circ} 28^{\prime} 03^{\prime \prime} \mathrm{N}$ and longitude $69^{\circ} 22^{\prime} 34^{\prime \prime} \mathrm{E}$ ) is just south of Mekhtar town and just east of Mekhtar-Chamalang road (toposheet 39F/7). This sandstone is oil reservoir rocks in Kirthar basin commonly called Goru Sandstone. It mostly consists of sandstone and siltstone with some shale and marl. At type locality it is round about $100 \mathrm{~m}$ thick lensoid shape Pab like quartzose sandstone. It is exposed in the Mekhtar area of Loralai, Murgha Kibzai area of Zhob and Dhana Sar area of Shirani district. Its lower contact with Sembar shale and upper contact with Goru Formation is sharp, abrupt and reduced transitional. Its age is Early Cretaceous.

Goru Formation: The Goru Formation was introduced by [33]. It consists of shale (grey, khaki and calcareous) and marl (grey, cream white, thin to thick bedded and porcellaneous). It is $300 \mathrm{~m}$ thick. Its lower and upper contact with Sembar and Parh formations is transitional and conformable. Its age is Early Cretaceous.

Parh Formation: The term Parh was introduced by [38]. The reference [33] redefined as limestone between Goru and Mughalkot formations. It consists of mainly limestone with minor marl and shale. Limestone is white, medium to thick bedded and porcellaneous. Marl is grey to cream white, thin to thick bedded and porcellaneous. Shale is grey, maroon and calcareous. At places cherty beds are common. It is $60 \mathrm{~m}$ thick. Its lower and upper contacts with Goru and Mughalkot formations are transitional and conformable respectively. Its age is Early Cretaceous.

Fort Munro Group: The Late Cretaceous Fort Munro Group was introduced by [6]. The type section Girdu and surrounding area just exposed on the sides of Fort Munro-Dera Ghazi Khan road (lat. 29 $57^{\prime} 14^{\prime \prime} \mathrm{N}$; long. $70^{\circ} 10^{\prime} 38^{\prime \prime} \mathrm{E}$; toposheet $39 \mathrm{~K} / 1$ ). Its upper contact with Sangiali Group is found in the Girdu area while its lower contact with Parh Group (i.e. the lower contact of Mughalkot Formation with Parh limestone) is exposed in Shadiani section (Toposheet $39 \mathrm{~J} / 4$ ) of 
Fort Munro area located on the north of Girdu area and on the core axis of Fort Munro anticline. Ai Shadiani section the OGDCL drilled hole of petroleum resources. Fort Munro Group includes the Mughal Kot, Fort Munro, Pab and Vitakri formations.

Mughalkot Formation: The term Mughal Kot Formation was introduced by [33]. It is exposed in the western and northern part of investigated area. It consists of shale and sandstone with minor marly beds. The shale is grey, khaki and calcareous. The sandstone is white to grey, quartzose, thin to thick bedded and medium to coarse grained, mostly weathered as dark grey to black. The marl is grey to cream white, thin bedded and porcellaneous. It is $1200 \mathrm{~m}$ thick in the north of study areas while in the west the thickness is reduced. Its lower and upper contact with Parh and Fort Munro formations is also transitional and conformable. Its age is Late Cretaceous.

Fort Munro Formation: The term Fort Munro member was introduced by [33]. The reference Fatmi 1977 upgraded as Fort Munro Formation. It consists of grey to brown and thin to thick bedded limestone with minor greenish grey shale. It is $100 \mathrm{~m}$ thick at type locality. Fort Munro limestone is pinching toward west. The lower contact with Mughal Kot Formation and upper contact with Pab Formation are transitional and conformable. Its age is Late Cretaceous.

Pab Formation: The term Pab Sandstone was introduced by [39] and the type section in the Pab Range was designated by [33]. The Pab Formation was divided into three members like lower Dhaola, middle Kali and upper Vitakri members [40]. The Dhaola member type section is Dhaola Range (latitude $29^{\circ} 42^{\prime} 41^{\prime \prime N}$; longitude $69^{\circ} 29^{\prime} 48^{\prime \prime} \mathrm{E}$ ) of Barkhan district. Dhaola member consists of white quartzose sandstone with minor to moderate black weathering representing proximal delta, near the coastline and consistent in the eastern Sulaiman and also Kirthar Foldbelts. The best reference section for Dhaola member is Fort Munro area (lat. $29^{\circ} 57^{\prime} 14^{\prime \prime} \mathrm{N}$; long. $70^{\circ} 10^{\prime} 38^{\prime \prime} \mathrm{E}$ ) of D.G.Khan district. The correct type section of Kali member is the Kali hill (Kali in Saraiki for black, Tor is for black in Pashto) located just south of Tor Thana and near the road (latitude $30^{\circ} 27^{\prime} 20^{\prime \prime} \mathrm{N}$; longitude $69^{\circ} 09^{\prime} 52^{\prime \prime} \mathrm{E}$ ) under the territory of Loralai district. Kali hill of Tor Thana is located on the southern bank of road (D.G.Khan-Loralai road) about $15 \mathrm{~km}$ west of Mekhtar town. Previously a Kali hill of Tor Thana was mistyped as Kali hill of Dhaola Range. Kali member is originated due to its Kali hill of Tor Thana of Mekhtar subtehsil of Loralai district. It is about $400 \mathrm{~m}$ thick and consists of shale and black weathering sandstone representing middle and distal deltaic environments and mostly exposed in the type section and surroundings. Both members seem to be coexisted at the surrounding of Dhadhar peak of Siah Koh anticline (northwest of Bahlol), while in most of other places both members are not coexisted at same locality, so they represent lateral variation. The Vitakri member which was later upgraded as formation (see below). The thickness of this formation is estimated $400 \mathrm{~m}$ at Rakhi Gaj, Rarkhan and Mazara area, while pinching toward west and it becomes few meters in the Sor Range area (base of 
Murdar Ghar) and Moro (Morove river, east of Johan village). In the Musafarpur and surrounding areas (territory of Qila Saifullah and Zhob districts) the dominant maroon shale and grey and white sandstone is considered as Vitakri Formation (detail as below). Its lower contact with Fort Munro Formation is transitional and conformable and upper contact with Vitakri Formation is disconformable. Age is Late Cretaceous.

Vitakri Formation: The Vitakri member (the upper member of Pab Formation) was introduced by [40] and later it was upgraded as Vitakri Formation [6] (Type locality Vitakri area, lat. $29^{\circ} 41^{\prime} 19^{\prime \prime N}$; long. $69^{\circ} 23^{\prime} 02^{\prime \prime E}$; Figure 5)) due to its distinct lithology, depositional environments and lateral extension [7]. Vitakri village is about $30 \mathrm{Km}$ in the south-southwest of Barkhan town. It consists of two units of variegated but dominantly maroon shale or mud intercalated and also capped by sandstone units. Its thickness varies from $1 \mathrm{~m}$ to $30 \mathrm{~m}$. It is common thought that in the Musafarpur and surrounding areas (territory of Qila Saifullah and Zhob districts) the maroon shale and white to grey sandstone are reposited, which indicates later age than Pab sandstone. Due to redeposition of Pab sandstone revealed latest Cretaceous age which is coeval to Vitakri Formation. Further the variegated and most common maroon lithology resemble and tele with Vitakri Formation. Third reason is the finding of archosaurs bones in Vitakri Formation of Vitakri area and footprints and tracks occurrence in Musafarpur and surrounding areas. Due to these reason the maroon shale and grey to white sandstone is assigned to Vitakri Formation. The Vitakri Formation is about $35 \mathrm{~m}$ thick in the Vitakri area of Barkhan district of Balochistan) and also in Khadro Bara area of Laki Range of Jamshoro district of Sindh province and more than $100 \mathrm{~m}$ thick in the Musaferpur area of Qila Saifullah and Zhob district of Balochistan province. Vitakri Formation host bones and also tracks of diverse archosaurs. Its lower contact with Pab Formation and upper contact with Sangiali/Rakhi Gaj Formation (Figure 1)-(Figure 4) are disconformable. Its age is Latest Cretaceous (Latest Maastrichtian 67 - $66 \mathrm{Ma}$ ) [32] [41] [42].

Sangiali Group: The Paleocene Sangiali Group proposed by [6] includes the Sangiali, Rakhi Gaj and Dungan formations.

Sangiali Formation: The Sangiali Formation introduced by [6]. It is exposed only in the Vitakri and surrounding areas. It consists of brown limestone, green sandstone with subordinate green shale. The limestone is brown, thin to medium bedded and bivalves bearing. The sandstone is green to grey, thin to thick bedded and fine to coarse grained, quartzose, and mostly weathered as dark grey to black. The shale is green and grey, and calcareous to noncalcareous. Some lowermost coquina beds including nautiloids of Sangiali formation are also observed just above the latest Cretaceous mud/sandstone of Vitakri Formation. This differentiation line is Cretaceous Tertiary Boundary. Its age is Early Paleocene.

Rakhi Gaj Formation: The lower Rakhi Gaj shales were introduced by [33] and Rakhi Gaj Formation was adopted by [4]. It is exposed in the central, north- 
ern, eastern and western parts of study area. It is subdivided into lower Girdu member (thick bedded grey to green and variegated ferruginous and fossiliferous sandstone) and upper Bawata member (green, grey and dark grey shale with some ferruginous and fossiliferous siltstone and sandstone) [7]. It derived from Deccan volcanics. It hosts low grade iron deposits in Fort Munro and surroundings [7]. In Mari Bugti hills (except Vitakri area and surroundings), the Rakhi Gaj sandstone is observed just above the Cretaceous Paleogene Boundary. It is $100-200 \mathrm{~m}$ thick. The lower contact with Sangiali (Vitakri areas) is conformable, with Vitakri (where Sangiali is missing) and Pab (where Sangiali and Vitakri both missed) formations are disconformable. The upper contact with Dungan Formation is conformable. Its age is Early Paleocene.

Dungan Formation: The term Dungan limestone was introduced by [43]. The type section was designated near Harnai [33]. It consists of limestone, shale and marl. At places it consists of dominant shale lithology like Mekhtar and Rakhi Gaj areas and at places it consists of dominant limestone lithologies like Mughalkot, Zinda Pir, Kaha Harrand, Maarri, Khattan, Dungan, etc. It is $100 \mathrm{~m}$ thick. Its lower contact with contact with Rakhi Gaj is conformable while with $\mathrm{Pab}$ and Mughalkot formations are disconformable. Its upper contact with Early Eocene Shaheed Ghat Formation is conformable. Its age is Late Paleocene.

Chamalang Group: Chamalang Group was first named by [44] and formally described by [7]. The Early Eocene Chamalang Group represents Shaheed Ghat, Toi, Kingri, Drug and Baska formations. The name Chamalang Group is preferred than Ghazij Group due to well exposed and thick individual formations with well lower and upper contact in Chamalang area and also easy accessibility. Further Kingri Formation is not well developed in the Spintangi area where Ghazij name was based; consequently the Chamalang Group was adopted [7] where all formations have well developed lower and upper contacts and vast extension. The type section for Chamalang Group is the Chamalang area (latitude $30^{\circ} 10^{\prime} \mathrm{N}$; longitude $69^{\circ} 25^{\prime} \mathrm{E}$ ).

Shaheed Ghat Formation: The Shaheed Ghat Formation was named by [45] for the upper Rakhi Gaj and green nodular shales of [46]. It is vastly exposed and forms valleys. It consists of mainly shale/mud with negligible silt and sandy beds. Its thickness varies from $400-1000 \mathrm{~m}$. Its thickness is relatively less in eastern Sulaiman foldbelt. Its lower contact with Dungan and upper contact with Toi Formation and Drug Formation (where Toi is missed) are conformable. Its age is Early Eocene.

Toi Formation: Toi Formation was suggested by S. M. Hussain of American Oil Company during meeting of stratigraphic Committee of Pakistan [4]. The type Toi Nala found in Mughal Kot area with mistyped grid reference by [4], while correct references are latitude $31^{\circ} 29^{\prime} \mathrm{N}$ and longitude $70^{\circ} 07^{\prime} \mathrm{E}$. It is exposed in the northern and western part of study area. It consists of marl, sandstone, shale and coal. As lateral variation, this formation is being thin and may be finishing in southern and eastern parts. And further north at the south of Mughal 
Kot the new delta of Toi Formation started again. Its lower and upper contact with Shaheed Ghat and Kingri formations and Drug Formation (where Kingri Formation is missed) is transitional and conformable. Its age is Early Eocene.

Kingri Formation: The term Kingri Formation was first used in 2009 [6]. The type section of Kingri Formation is the just northwest of Kingri town at latitude $30^{\circ} 28^{\prime} \mathrm{N}$; longitude $69^{\circ} 47^{\prime} \mathrm{E}$ [7]. It consists of terrestrial mollase reds shale/mud with subordinate grey sandstone. The shale is mostly red and maroon and sandy and silty and calcareous. It is exposed in the northern and western parts of study area. It is $700-1000 \mathrm{~m}$ thick in the type section (Kingri area of Musakhel district, Balochistan) and also same in Drazinda Shirani section (FR D.I.Khan, Khyber Pakhtunkhwa). It extends toward Mach and Johan (Kalat), Balochistan in the southwest and also extends in the north upto Hangu (Kohat sub basin) where it is called Gurguri sandstone. It represents the flood plain or overbank fines along with channel sandstone. It is pinching rapidly eastward and absent in areas of D.G. Khan, Rajan Pur and Dera Bugti districts. Its lower contact with Toi and upper contact with Drug Formation are disconfirmable. Its age is Early Eocene.

Drug Formation: The name Drug Formation was used by [45] for the rubbly limestone of Eames [46]. The reference [4] mentioned the wrong order or position of Ghazij group formations like Toi and Drug formations. The actual position of Toi Formation is below the Drug Formation while [4] mentioned every where the Toi formation is above the Drug formation. It is confirmed in the north and southwest of Sulaiman foldbelt. It is exposed well Mari Bugti hills and surroundings. It consists of rubbly limestone, marl and shale. The thickness of this formation is decreasing toward north and absent in the Mughal Kot section. Its lower contact with Kingri Formation, with Shaheed Ghat Formation (where Kingri and Toi formations are missed especially in the eastern and southeastern part of Mari Bugti hills and surroundings) and upper contact with Baska Formation is conformable. Its age is Early Eocene.

Baska Formation: The name Baska shale is proposed by the [47] to replace the descriptive term "shale with alabaster" of [46]. It is widely exposed in the Mari Bugti hills and surroundings. It consists of thick gypsum beds, shale, siltstone and marl. The gypsum is grey to grayish white, medium to thick bedded and massive. The shale is grey, khaki and calcareous. The siltstone is greenish grey to grey and thin to medium bedded. The marl is cream white, thin to medium bedded and porcellaneous. The shale is grey, khaki and calcareous. Its thickness is estimated $100 \mathrm{~m}$. Its lower contact with Drug Formation and upper contact with Habib Rahi Formation are conformable. Its age is Early Eocene.

Kahan Group: The Kahan Group was introduced in 2009 [48] after Kahan village. The type section designated near the village of Kahan at latitude $29^{\circ} 17^{\prime} \mathrm{N}$; longitude $68^{\circ} 50^{\prime} \mathrm{E}$ (previously mistyped in [7] [10]). The individual formations are well exposed on the northern and southern limbs of Kahan syncline which is generally trending east-west. The Early to middle Eocene Kahan Group includes 
the Habib Rahi, Domanda, Pir Koh and Drazinda formations.

Habib Rahi Formation: The Habib Rahi limestone was used by [49]. The type locality grid reference (lat. $29^{\circ} 06^{\prime} 10^{\prime \prime N} \mathrm{~N}$ long. $69^{\circ} 02^{\prime} 30^{\prime \prime} \mathrm{E}$ ) was first reported by [7] which are located $10-15 \mathrm{~km}$ in the west of Dera Bugti town and geologically located on the southern limb of Pir Koh anticline [7]. It consists of white to light brown porcellaneous limestone and marl and grey shale. Its thickness at southern limb of Pirkoh anticline is estimated $80 \mathrm{~m}$ with vertical changes as 40 $\mathrm{m}$ limestone alternated with shale and marl, $33 \mathrm{~m}$ shale, and upper $7 \mathrm{~m}$ limestone. As lateral variation, this formation is relatively more and maximum thick in the south than the exposures in the eastern and northern Sulaiman foldbelt. Its lower contact with Baska Formation and upper contact with Domanda Formation are transitional. Its age is Early Eocene.

Domanda Formation: The Drazinda shale member was used by [46]. It consists of mainly shale/mud with one bed of gypsum ( 1 - $5 \mathrm{~m}$ thick; maximum thick at eastern part of Nisau syncline). Its thickness at southern limb of Pirkoh anticline is estimated $80 \mathrm{~m}$ which comprised of vertical variations as $50 \mathrm{~m}$ shale, 1 - $2 \mathrm{~m}$ gypsum bed, and upper 25 - $30 \mathrm{~m}$ chocolate and khaki shale. The thickness of this formation is relatively less in the south than exposures in the eastern and northern Sulaiman foldbelt. Its lower contact with Habib Rahi Formation and upper contact with Pirkoh Formation is transitional and conformable. Its age is early to middle Eocene.

Pirkoh Formation: White marl band of [46] has been used as Pir Koh limestone member by [47]. It was used as Formation by [4]. It consists of white porcellaneous limestone and marl, and grey shale. At type locality its thickness is estimated $130 \mathrm{~m}$ which comprising of $20 \mathrm{~m}$ chalky white limestones and marl with minor shale, $20 \mathrm{~m}$ shale with chalky white marl, $40 \mathrm{~m}$ white to light brown, thin bedded limestone, $40 \mathrm{~m}$ light brown rubbly limestone. Its thickness is relatively more and maximum at typelocality area than the other exposures in the eastern and northern Sulaiman foldbelt. Its lower contact with Domanda Formation and upper contact with Drazinda Formation is transitional and conformable. Its age is early to middle Eocene.

Drazinda Formation: The Drazinda shale member was used by [47]. It was used as Formation by [4]. It consists of mainly shale/muds, and marl. The shale is chocolate, khaki and calcareous. Marl is cream white, thin to thick bedded, massive and porcellaneous. Its thickness at Pirkoh section is estimated $120 \mathrm{~m}$ which comprising of $12 \mathrm{~m}$ chalky white marl and shale, $40 \mathrm{~m}$ chocolate shale, 12 $\mathrm{m}$ chalky white marl and shale, 40 - $45 \mathrm{~m}$ chocolate shale, and upper $12 \mathrm{~m}$ chalky white to grey marl and shale. Its thickness is maximum at type area and relatively less in Mari Bugti hills of southern Sulaiman. Its lower contact with Pirkoh Formation is conformable while upper contact with Chitarwata Formation is disconformable. Its age is early to middle Eocene.

Vihowa Group: The term Vihowa Group was first used in 2009 [6]. Its type section is Vihowa Rud (latitude $31^{\circ} 04^{\prime} \mathrm{N}$; longitude $70^{\circ} 16^{\prime} \mathrm{E}$ ) [7]. The Oligo- 
cene-Pliocene Vihowa Group includes the Chitarwata, Vihowa, Litra and Chaudhwan formations.

Chitarwata Formation: It was first used by [47]. Its type section is Chitarwata Post (lat. $31^{\circ} 03^{\prime} \mathrm{N}$; long. $70^{\circ} 14^{\prime} \mathrm{E}$ ). It consists of mainly terrestrial sandstone, shale and conglomerate. Its thickness estimated in Dera Bugti areas is $130 \mathrm{~m}$ which comprising of $3-4 \mathrm{~m}$ red mud, $1 \mathrm{~m}$ basal conglomerate and 125 $\mathrm{m}$-alternated sandstone with shale and conglomerate. It is prominent resistant ridge forming. Its lower contact with Domanda Formation and upper contact with Vihowa Formation is disconformable. It is synonymous with Bugti bone beds or Bugti formation. It is the host of largest land mammals found at Dera Bugti and Taunsa areas. Its age is Oligocene.

Vihowa Formation: It was used by [47]. It consists of terrestrial shale, sandstone and conglomerate with general pink maroon appearance. It is $500-650 \mathrm{~m}$ thick at Dera Bugti area. Its lower contact with Chitarwata and upper contact with Litra Formation is disconformable. It hosts continental vertebrates. Its age is Oligocene-Miocene.

Litra Formation: It was first used by [47]. It consists of terrestrial grey to green sandstone with subordinate shale and conglomerate. It is $500 \mathrm{~m}$ thick at Dera Bugti areas. Its lower contact with Vihowa and upper contact with Chaudhwan Formation is disconformable. It is the host of continental vertebrates. Its age is Miocene.

Chaudhwan Formation: It was first used by [47]. It consists of terrestrial alternated maroon mudstone/shale, sandstone and conglomerate. It is $500-650 \mathrm{~m}$ thick at Dera Bugti areas. Its lower contact with Litra Formation is disconformable and upper contact with Dada Formation is disconformable and at places angular. This formation is the host of continental vertebrates. Its age is Miocene-Pliocene.

Sakhi Sarwar Group: The name of Sakhi Sarwar Group was proposed in 2012 [28]. The type section is designated here at latitude $29^{\circ} 59^{\prime} 37^{\prime \prime} \mathrm{N}$ and longitude $\left.70^{\circ} 18^{\prime} 04^{\prime \prime} \mathrm{E}\right)$ which is located at the west of Sakhi Sarwar town and also on the west of D.G.Khan-Fort Munro road. The Pleistocene-Holocene Sakhi Sarwar Group [28] includes the Pleistocene Dada (mainly conglomerate) and Holocene Sakhi Sarwar (clays, silt, sandstone and conglomerate) formations [28].

Dada Formation: Its name derived from Dada River (lat. $29^{\circ} 50^{\prime} \mathrm{N}$; long. $68^{\circ} 03^{\prime} \mathrm{E}$ ) at south of Spintangi Railway station [1]. It consists of prominent resistant belt of conglomerate with subordinate shale and sandstone. Its lower contact with Dhok Pathan and upper contact with Sakhi Sarwar formations are disconfirmable and at places angular. It is 200 - $300 \mathrm{~m}$ thick at Sakhi Sarwar (D.G.Khan) and type area. Its lower contact with Chaudhwan Formation and upper contact with Sakhi Sarwar is conformable and at places angular especially with subrecent alluvium. Its age is Pleistocene.

Sakhi Sarwar Formation: Sakhi Sarwar Formation was named in 2012 [28]. The type section is designated here (latitude $29^{\circ} 59^{\prime} 37^{\prime \prime} \mathrm{N}$; longitude $70^{\circ} 18^{\prime} 04^{\prime \prime} \mathrm{E}$ ) 
which is located on the west of Sakhi Sarwar town and also on the west of D.G.Khan-Fort Munro road. Further it is also well developed and well exposed (latitude $29^{\circ} 59^{\prime} 37^{\prime \prime} \mathrm{N}$; longitude $70^{\circ} 18^{\prime} 04^{\prime \prime} \mathrm{E}$ ) on the northern plunge of Choti Bala anticline just on the east of Sakhi Sarwar town and just near the south of D.G.Khan-Fort Munro metallic road. It is exposed in the southern and eastern part of study area. Sakhi Sarwar Formation consists of varicolored clays, sandstone, siltstone and conglomerate. It is $200-300 \mathrm{~m}$ thick at type area. Its lower contact with Dada conglomerate and upper contact with Subrecent alluvium is transitional and at places anugular. Its age is Holocene.

Subrecent and Recent deposits: These are found as Terrace Alluvial deposits; Fan Alluvial deposits; Colluvial deposits; Mixed sand, silt and clay deposits (non-cultivated lands); Mixed sand, silt and clay deposits (cultivated lands); and Present Channel alluvial deposits.

\subsection{Structure of Mari Bugti Hills and Surrounding Areas, Balochistan, South Punjab and North Sindh, Pakistan}

The major folds (alternated anticlines and synclines) and major faults in the different parts of Mari Bugti hills and surrounding areas are presented as below. Many of the following mentioned large anticlines and synclines in actual are anticlinoria and synclinoria because they have superimposed minor foldings.

\subsubsection{Major Folded Structures (Alternated Anticlines and Synclines) in the North Eastern Part of Mari Bugti Hills and Surrounding Areas, Balochistan and South Punjab, Pakistan}

The major foldings in the north eastern part of Mari-Bugti hills and surrounding areas are represented (started from east to west) as Choti Bala anticline (open, low dip), Sakhi Sarwar syncline (open, low dip), Zinda Pir anticline (open, low dip), Barthi syncline (open to moderate dip limbs), Fort Munro-Maarri anticline (western limb is low dip while eastern limb is mostly moderate to high dip), Manjhail syncline joined along strike with Rakhni-Chacha-Beaker syncline which again joins with Janthali syncline (mostly low and moderate dip), Phulali anticline (easterly flanked by major Kingri-Rarkhan thrust) joined along strike with Pikal anticline which also join with Siahkoh anticline and then Tadri-Khatan-south Mandai anticline (moderate to high dip), Kachar syncline joined with Jhabar-Nisau-Safed syncline (mostly low to moderate dip), Mazara-Dhaola-Andari-Chapar anticline which have plunged downward and again emerged in the strike direction as Triman-Khatan anticline (moderate to high dip), Basti Nala Gambrak-Vitakri Thana-Makhmar syncline (low to high dip), Vitakri dome anticline joins with Mari Bohri-southern Fazil Chel anticline (mostly low to moderate and partially high dip) plunged which join with eastern plunge of Mawand syncline, Eshani-Barkhan-Bohri Kachi syncline joins with Mawand syncline which join with Mandai syncline (mostly low to moderate dip), Kachi Bohri-Fazil Chel-Gamboli anticline which have faulted contact with Jandran anticline (tight to moderate dip), Kohlu syncline (low to high dip), Kali Chapri anticline (low to moderate 
dip) joined with Kishk anticline (mostly tight anticline representing high dip), Girsini-Pazha syncline (low to high dip) and Nosham-Bala Dhaka-south HosriMazar Drik anticlines (Figures 5-7). Kohlu syncline has W-shaped western plunge. Structure of northeastern areas like Fort Munro quadrangle $39 \mathrm{G} / 13$, Kingri quadrangle 39 F/15 and Toi Nala-Ghoze Ghar-Shin Ghar quadrangle 39 $\mathrm{I} / 4$ are shown as below.

The Fort Munro quadrangle (39 G/13) area consists of many alternations of

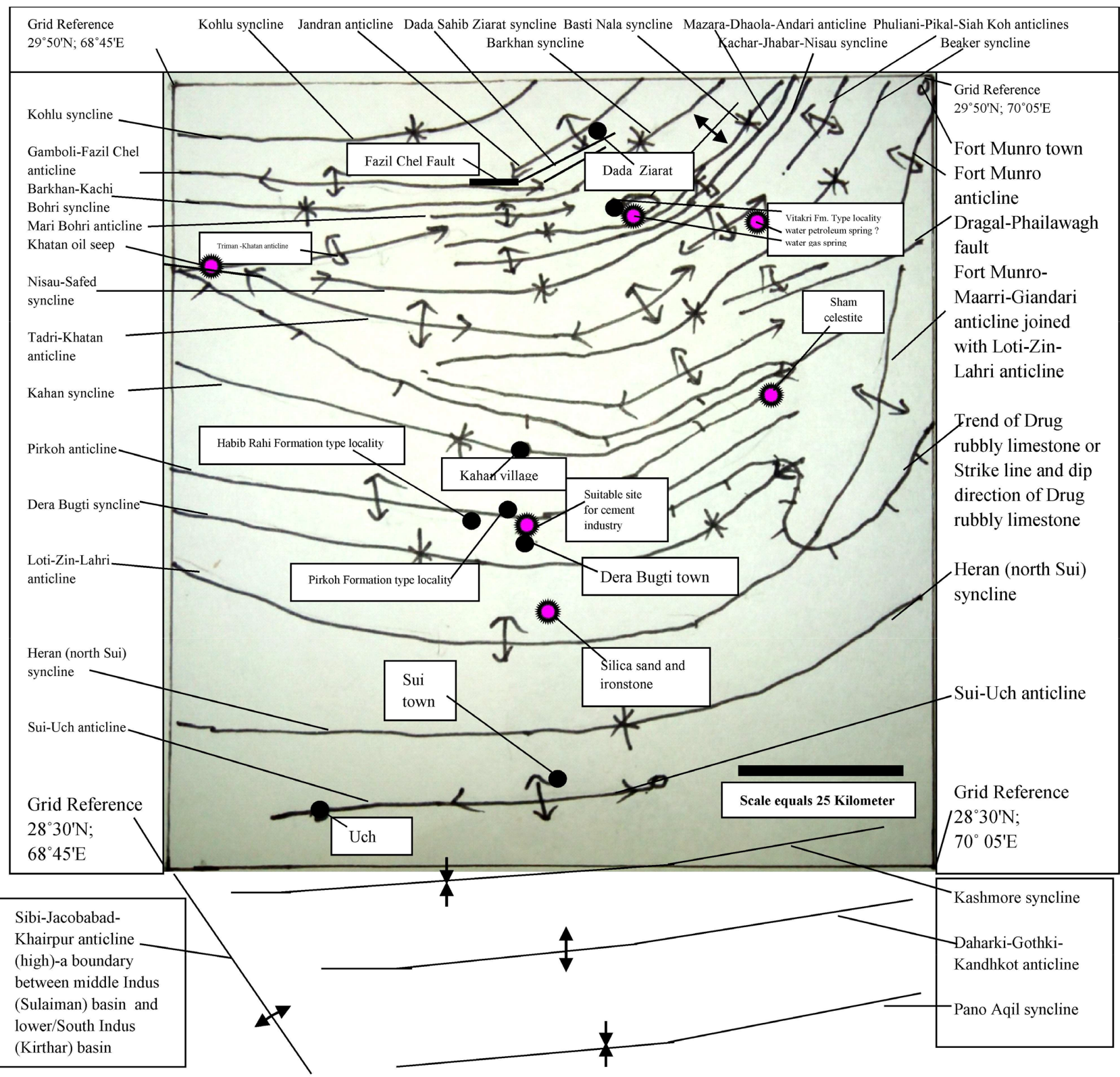

\section{Anticline
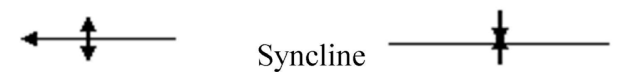 \\ K-Pg Boundary \\ Road/track-longer dashed line}

Figure 5. Structural mapping (foldings-anticlines and synclines) of Mari Bugti hills and surrounding areas, Balochistan, South Punjab and North Sindh, Pakistan. The structures in the north Sindh areas like Kashmor, Daharki, Ghotki, Kandhkot, Pano Aqil, Khairpur, Jacobabad and surroundings are interpreted because of mostly alluvium cover. For legend and symbols, see Figure 3. 


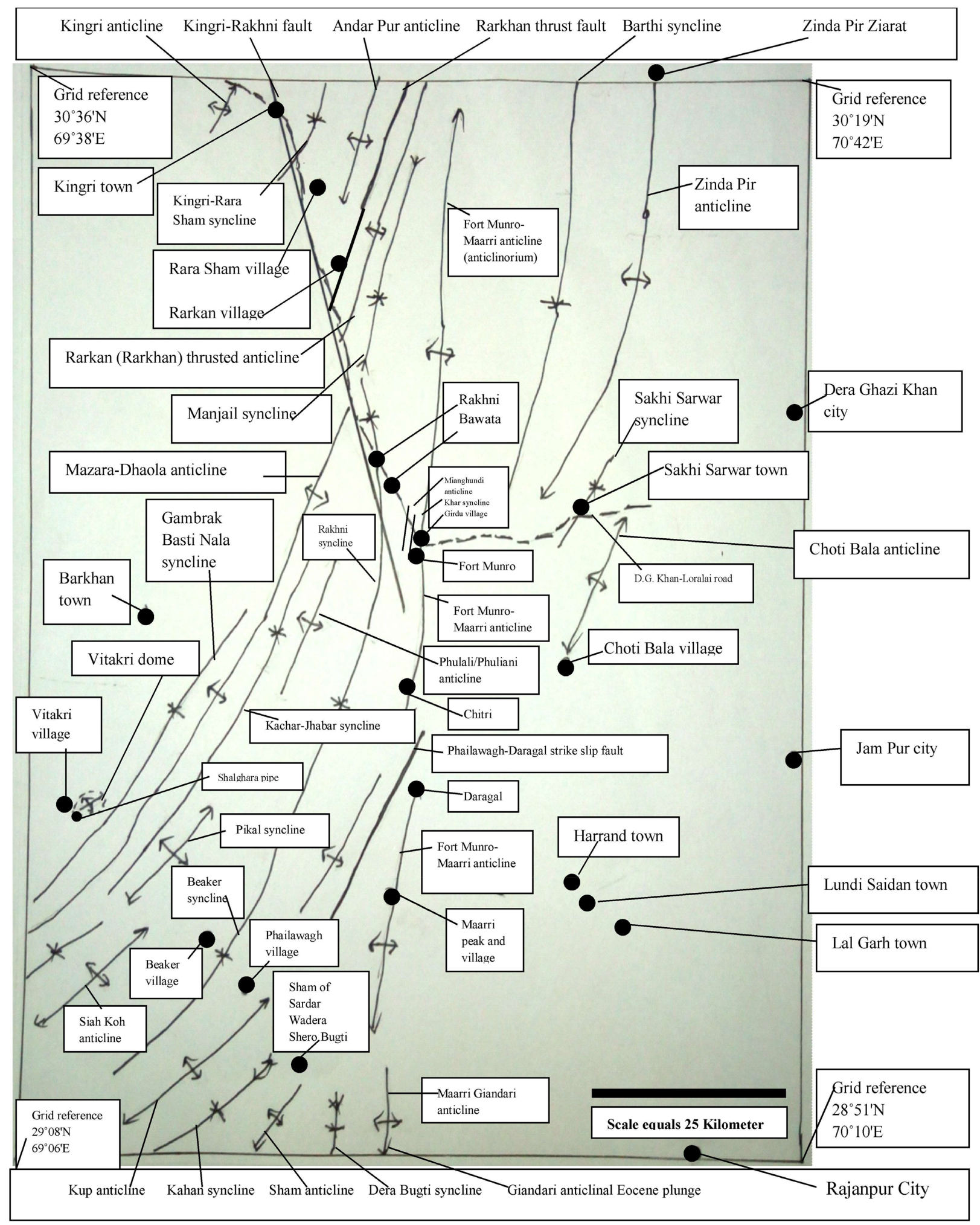

Anticline

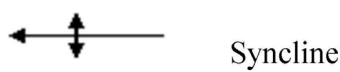

K-Pg Boundary

Road/track-longer dashed line

Figure 6. Structural major folds (anticlines and synclines) and faults of eastern Mari Bugti hills of Balochistan Province, Fort Munro-Maarri and Zinda Pir anticlines of eastern Sulaiman arc and Sulaiman foldbelt, South Punjab, Pakistan. For legend and symbols, see Figure 3. 


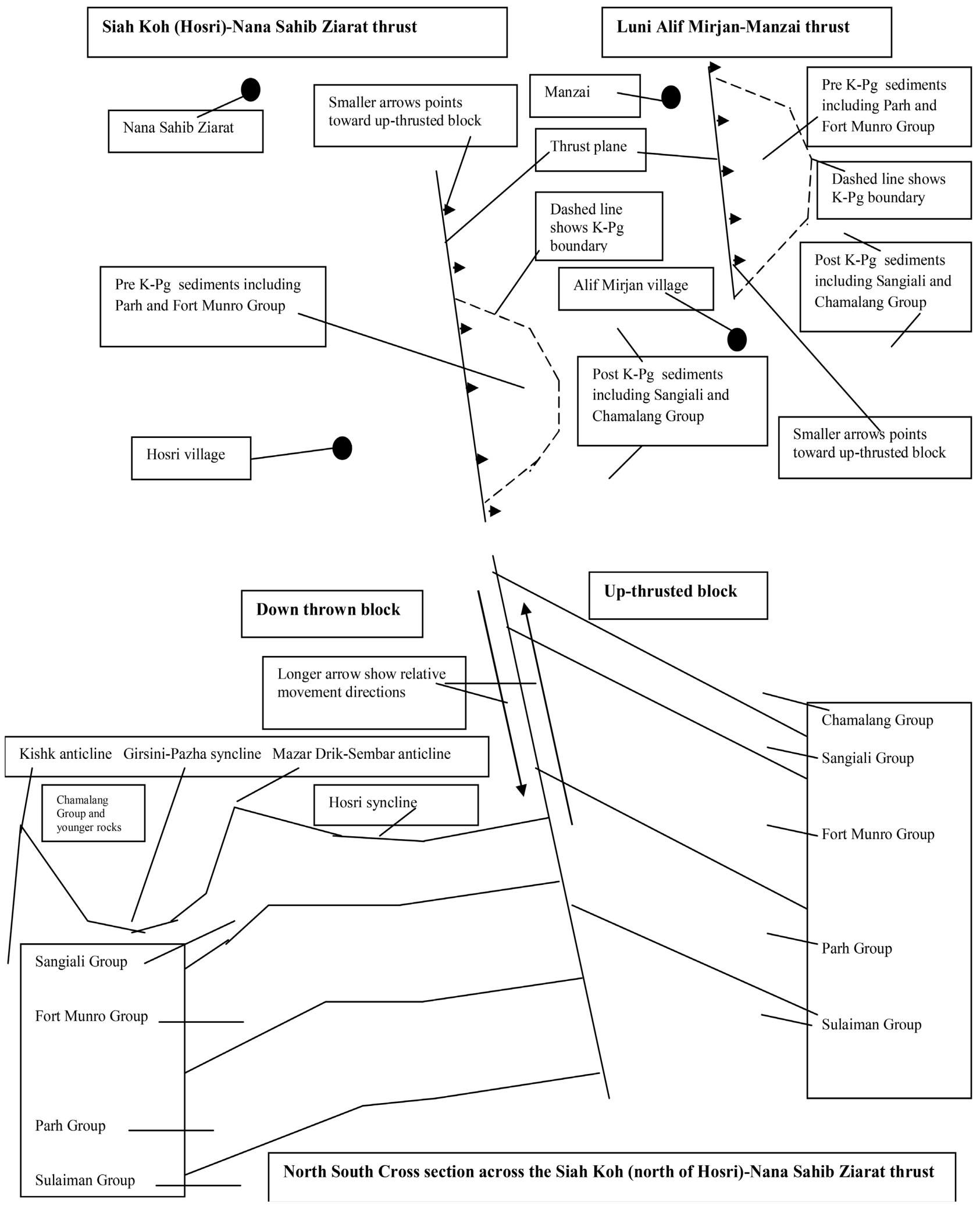

Figure 7. Upper maps, Imbricated thrust faults. Geological Map of Siah Koh (north Hosri)-Nana Sahib Ziarat thrust and Luni Alif Mir Jan-Manzai thrust. Lower map, Cross section profile with interpreted subsurface sediments across Siah Koh (north Hosri)-Nana Sahib Ziarat thrust to Kishk anticline. These thrusts are located in the northern part of Mari Hills and surroundings, Kohlu and Loralai districts, Balochistan Province, Pakistan. 
synclines and anticlines generally trending N-S and NE. Starting from west, the Mazara anticline is located in the western part of Fort Munro quadrangle area and represent moderate to high dips, and Late Cretaceous Goru and Parh Formation as exposed oldest core formations. The Mazara anticline joins with the Dhaola-Andari anticline in the southwest and plunged at Chapar area and then Triman anticline started. Kachar (-Jhabar-Nisau) syncline located in the western part of area and includes moderate dips of strata and Domanda as core formation. The Phulali anticline is found in the western and central part with low to high dips and Pab as core formation. The Phulali anticline joins with Pikal and Siah Koh anticlines in south and southwest and further joins with Tadri-Khatan anticline. Chacha syncline is located in the central part and has low dips and Shaheed Ghat as core formation. The core of Fort Munro-Maarri anticlinorium has Parh limestone at Shadiani and Mughalkot Formation at Girdu. It is located on eastern part and represents low to moderate dips of western limb and moderate to high dips on eastern limb. Fort Munro anticlinorium plunges northward just east of Kharar Buzdar and plunges southward at Maarri peak [15].

The northern part of study area like Kingri quadrangle (toposheet $39 \mathrm{~F} / 15$ ) consists of many alternations of synclines and anticlines generally trending NE. Starting from northwest, the Kingri anticline is located in the northwest of Kingri quadrangle area and represent moderate to high dips, and latest Cretaceous Mughal Kot as core formation. Kingri syncline located in the northern western part of area and include moderate to high dips of strata and possible Domanda (covered by alluvium) as core formation. The Mirri Wah anticline is found in the southwestern side of central part with low to moderate dips and Shaheed Ghat as core formation. The Andar Pur anticline is found in the eastern part of area with low to moderate dips and Dungan as core formation. Rarkhan (Rarkan) syncline is located in the eastern part and has low to moderate dips and Drug is the Core Formation. This syncline is followed by Rarkhan Thrust fault. Manjhail syncline is located on the south eastern corner of area with moderate to high dips on limbs and Drazinda as core formation. Kingri strike slip fault (left lateral fault) trending NNW crosses the Kingri quadrangle area [25].

Further north the Toi Nala-Ghoze Ghar-Chitarwata quadrangle (toposheet 39 $\mathrm{I} / 4$ ) consists of many alternations of synclines and anticlines generally trending N-S and NE. Starting from west, the Shin Ghar anticline is located in the western part of quadrangle area and represent moderate to high dips, and Middle Jurassic Chiltan limestone as core formation. Nishpa syncline located in the western part of area and include moderate to high dips of strata and Domanda as core formation. The Tangi Sar anticline is found in the western and central part with low to moderate dips and Mughal Kot as core formation in the quadrangle area. Savi Ragha syncline is located in the eastern part and has low to moderate dips and Drazinda as core formation. Pahlwan Kach anticline is located on the eastern part of area with moderate to high dips on limbs and Shaheed Ghat as core formation [27]. The structures of Musa Khel Bazaar quadrangle (Survey of Pa- 
kistan toposheet $39 \mathrm{~F} / 13$ ) were reported by [24].

\subsubsection{Structures of Northern Part of Mari Bugti Hills and Surrounding Areas, Balochistan Province, Pakistan}

The structural features of northern areas are Barkhan-Kachi Bohri syncline joined with Mawand syncline (low to moderate dip), northern Kachi Bohri-Fazil Chel-Gamboli anticline, Dada Sahib Ziarat syncline (low to moderate dip), Jandran anticline, Kohlu syncline (low to high dip; western plunge is w-shaped) and Kali Chapri anticline joined with Kishk-northern Gamboli anticline (Kali Chapri anticline is low to moderate dip; Kishk anticline is thrusted mostly high dip anticline), Pazha syncline (high to moderate dip), Mazar Drik Sembar anticline (north of Pazha), thrusted Siah Koh Hosri anticline and thrusted Alif Mirjan-Manzai anticline, southern Duki anticline (low dip) and Duki city syncline (low to moderate dip) (Figures 3-7). Further the major structures of northern areas like Chamalang-eastern Hosri quadrangle (39 F/8) and Bahlol-Baghao quadrangle (39 F/12) areas consists of many alternations of synclines and anticlines generally trending NE. Starting from northwest, the Dhadhar Koh anticline is located in the northwestern corner of quadrangle area and represent moderate dips, and latest Cretaceous Mughalkot as core formation. Bahlol syncline located in the northwestern part of quadrangle area and include moderate to high dips of strata and Domanda as core formation. Its southeastern limb is mostly overturned. It followed by the Nosham anticline which shows moderate to high dips, and north western limb is mostly overturned, and Dungan as core formation. Chuchandai syncline is located in the central part and has moderate to high dips and Drazinda as core formation. This syncline is followed by Lundi Sar anticline with moderate to high dips and Toi as core formation. Baghao syncline is located in the eastern part and has moderate to high dips and Domanda as core formation which is mostly covered by alluvium. This syncline is followed by Chapar anticline with moderate to high dips and Drug as core formation. Nizamwali syncline is located in the eastern part and has moderate to high dips and Drug as core formation. This syncline is followed by Lohari anticline with moderate to high dips and Drug as core formation. Narwel anticline is located in the southeastern part and has moderate to high dips and Drug as core formation. Narwel syncline is located in the southeastern part and has moderate to high dips and Drug as core formation. Nodo syncline is located in the southeastern part of quadrangle and has moderate to high dips and Shaheed Ghat as core formation [22] [23]. Further the structures of northern surroundings of Mari Bugti areas like Spin Ghar, Tatre and Gadebar anticlines and other folding reported in Mekhtar quadrangle 39 F/7 [21], Kotkai-Tor Thana quadrangle 39 F/3 [19], Shabozai quadrangle 39 B/15 [18] and Loralai quadrangle 39 B/11 [17].

\subsubsection{Structure of Southeastern and Southern Part of Mari Bugti Hills and Surrounding Areas, Balochistan, South Punjab and North Sindh, Pakistan}

The major foldings (generally trending east west) in the southeastern and south- 
ern part of Bugti hills (started from south to north) are Khairpur-Jacobabad anticline and high (mostly subsurface, very low dip), Pano Aqil syncline (mostly subsurface; very low dip), Daharki-Ghotki-Kandhkot anticline (mostly subsurface; very low dip), Kashmore-Ashir Domki-Sohbat Khan Khoso syncline (mostly subsurface; very low dip), Sui-Uch Anticline (very low dip), Heran (northern Sui) syncline (low dip), Loti-Zin-Lahri anticline (mostly low to moderate dip), Dera Bugti-Bangzila syncline (low to moderate dip), Pir Koh anticline (low to moderate dip; westward extends upto south of Talli village), Kahan-Talli-Sibi syncline (low to moderate dip), Phailawagh anticline (low dip), Beaker-Janthali syncline (low to moderate dip), Siah Koh anticline joined along strike with Tadri-Khatan-south Mandai anticline (moderate to high dip; extends upto north of Talli and Sibi city), Jhabar-Nisau-Safed syncline (low to moderate dip), Mazara-Dhaola-Andari-Chapar anticline joined along strike with Triman-Khatan anticline (moderate to high dip; extends upto Khatan area), Basti Nala Gambrak-Vitakri Thana-Makhmar syncline (low to medium dip), Vitakri dome anticline joined along strike with Mari Bohri-Southern Fazil Chel anticline (low to moderate dip), Barkhan-Kachi Bohri syncline joined along strike with Mawand syncline (low to moderate dip), north Kachi Bohri-Fazil Chel-Gamboli anticline, Dada Sahib Ziarat syncline and Jandran anticline (Figures 3-6). Further alternation of Kahan syncline, Kishk anticline, Pazha syncline and Mazar Drik anticline were found. Some overlapping structures mentioned here for easy understanding.

Fort Munro-Maarri anticline is faulted at Daragal just south of Chitri. Its southern plunge radiated into many anticlines and synclines (from east to west) are the Giandari anticline joined along strike with Loti-Zin-Lahri anticline, Dera Bugti syncline, Pir Koh anticline, Kahan-Talli syncline, Kup anticline, Phailawagh syncline, Moranj anticline and Beaker-Janthali syncline. Further westward structures reported above.

In Sham quadrangle 39 G/7 (named after the Sardar Wadera Shero Bugti Sham), the intense imbrications of faults are observed in the Janthali and Loop-Kulchas (Kalchas) synclinal areas. The area consists of many alternations of synclines and anticlines generally trending NE. Starting from northwest, the Siah Koh anticline which represent moderate to high dips, and latest Cretaceous Mughalkot as core formation. Janthali syncline located in the northern western part of quadrangle and includes moderate dips of strata and Drazinda as core formation. The Kup anticline is found in the central part of quadrangle with low to moderate dips and Dungan as core formation. Loop-Kulchas syncline is located in the southeastern part of quadrangle and has low to moderate dips and Drazinda as core formation. This syncline is enriched in imbrications of Drug, Baska and Habib Rahi formations. Sham anticline is located on the southeastern corner of quadrangle with moderate dips on limbs and Shaheed Ghat as core formation [14].

The Dera Bugti town, type localities of Habib Rahi and Pirkoh formations and 
surrounding areas (toposheet $39 \mathrm{G} / 4$ ) consist of many alternations of synclines and anticlines (Figure 5). Starting from north, the Kahan syncline generally trending EW have moderate dips. The core formation is the upper Vihowa group and limbs are of Kahan group. Danda anticline is also located in the north of toposheet $39 \mathrm{G} / 4$ area and trends generally EW with moderate dip limbs of Kahan and Vihowa group. The core formation is the Habib Rahi Formation. Pathar Nala syncline located in the northern part of mapped area and trends EW with northern limb with moderate dip and southern limb with low dips. Vihowa group and Dada formation is found in core. The Pirkoh anticline is found in the northern part with general EW trend with low dips of both limbs. The Pirkoh anticline is intensely faulted like NS strike slip faults and EW thrust fault. Marav syncline with general trend EW is located in the central part of quadrangle and has low north limb dip and moderate southern limb dip. Kumbas anticline is located on the eastern part of central area of quadrangle with moderate dips on limbs. The core formation is Pirkoh limestone. Dera Bugti syncline is located in the southern part of quadrangle, general trend EW, with low to moderate both limbs dips. The southern limb of Dera Bugti syncline is shared with the northern limb of Zin (Loti Anticline) the axis of which is located just on the southern vicinity of mapped area [11].

\subsubsection{Structure of Southwestern Part of Mari Bugti Hills and Surrounding Areas, Balochistan Province, Pakistan}

In the Mandai-Babar Kach-Badra-Sangan-e-Pain areas of Sibi and Bolan (Kachi/ Dhadhar) district, the synclines are open (low dip) while anticlines are tight or closed (high dip). The axis of folding in these areas are generally north south in the west and east west in the east. The Gamboli foldings (atleast four anticlines alternated by four synclines) started from Mawand (east) run upto Spin Tangi areas (west) and traversing from Mandai-Babar Kach (south) areas to Pazha areas (north) (Figure 5). Further north Pazha syncline, Mazar Drik Sembar anticline, southern Duki anticline (low dip) and Duki syncline (low to moderate dip). The westward from Sangan-e-Pain areas, the Marwar-Zardalu anticline and Urak synclinorium occurred. Many foldings are found in the Gamboli, Pazha and Spin Tangi areas (westward from Mawand to Spin Tangi to Harnai to Ziarat areas), here Pre K-T boundary rocks form the core of anticlines and post K-T rocks found on the core and also on limb of anticlines and synclines. Here latest Cretaceous Pab sandstones, Paleocene Dungan and Eocene Drug, Habib Rahi and Pirkoh limestones form the peak of structures due to resistant lithology, while dominant shale lithology form the valleys and sub plain areas. It is very interesting that a continuous exposure of Shaheed Ghat shale capped by Drug rubbly limestones is found as belt in the easternmost Sulaiman foldbelt and also from Phailawagh to Sori and Lehri Nala (north of Kahan and south of Tadri) to south of Khatan to south of Gamboli to south of Spin Tangi-Harnai-ShahrigKhost-Zardalu. Further southward from Drug rubbly limestones belt, the Chamalang (upper), Kahan, Vihowa and Sakhi Sarwar groups are exposed. 


\subsubsection{Major Faults in the Mari Bugti Hills and Surrounding Areas, Balochistan and South Punjab, Pakistan}

The following major faults are found in the Mari-Bugti hills and surrounding areas of Balochistan, South Punjab and Khyber Pakhtunkhwa provinces (Pakis$\tan )$. Hosri-Nana Sahib Ziarat thrust fault trending generally east-west and upthrusted and travelled more than $1 \mathrm{~km}$ (relative movement) by upthrusted wall/limb (Figure 7). Here the oldest Sembar shale along with other formations of Parh Group and caped by Fort Munro and Sangiali is thrusted on possible Early Eocene Shaheed Ghat shale of Chamalang Group. Here the lower Cretaceous Sembar shale seems to be contacted with Early Eocene Shaheed Ghat shale. The other imbricated thrust is Luni-Alif Mir Jan-Manzai thrust. Here the oldest Parh limestone of Parh Group and caped by Fort Munro and Sangiali is thrusted on possible Early Eocene Shaheed Ghat shale of Chamalang Group. Here the Parh limestone seems to be faulted contacted with Shaheed Ghat shale. Both these thrust show imbrications style (Figure 7).

The Rarkhan-western Hinglun Thrust fault is trending generally northeast-southwest and upthrusted and travelled more than $1 \mathrm{~km}$ (relative movement) by the upthrusted limb. Here the oldest Pab sandstone of Fort Munro Group and caped by Sangiali Group is thrusted on possible Early-middle Eocene Drug rubbly limestone of Chamalang Group. Here the Pab sandstone has faulted contacted with Drug rubbly marly limestone. The Rarkhan village and southward road to Rakhni upto Chapar bend is situated on the thrust line. The Drug rubbly marly limestone is exposed on the southwest of Rarkhan village and just southeast of last Rarkhan petrol pump and also just south of PTCL tower track. This trust line partially overlapped with Kingri-Rakhni fault (Figure 6).

The Domanda-Zamri-Sata Post-eastern Gulki Thrust fault is trending generally north-south and upthrusted and travelled more than half kilometer by the upthrusted limb. At Domanda area the oldest Baska gypsum of Chamalang Group (and caped by younger strata upto Chaudhwan formation of Vihowa Group and Dada and Sakhi Sarwar formations of Sakhi Sarwar Group) is thrusted on different formations mostly Drazinda and Domanda shales. It runs upto north at the mid distance between Drazinda and Draban town and further northward covered by alluvium. This fault extends discontinuously upto southward to Zamri, Sata Post and east of Gulki area.

The Kachi Bohri thrusted pipe is also found on the eastern plunge of Kachi Bohri-Fazil Chel-Gamboli anticline. Here red to maroon muds and grey to white sandstone of latest Cretaceous Vitakri Formation (along with Pab sandstone) were uplifted and extruded as pipe like. This thrusted pipe forms colluvial gravity flows on adjacent younger sediments (Figure 3). It is necessary to mention that there are atleast three Bohri localities like first is Mari Bohri (Barkhan district), the second Kachi Bohri locality (Barkhan district) which is about $5-6 \mathrm{~km}$ toward north from Mari Bohri locality, the third locality is Bohri locality just south of Kohlu town (Kohlu district). Like this but relatively small and low Shalghara thrusted pipe was also found in Shalghara locality (locality 3 of dino- 
saurs from Pakistan [9] [32] [42]) of Vitakri dome (Figure 6). Fazil Chel fault was found on the contact of southeastern plunge of Jandran anticline and northern limb of Fazil Chel anticline (Figure 5).

Major strike slip fault is Kingri-Rakhni fault. This fault is more than $50 \mathrm{~km}$ long starting from Chacha (Rajanpur district) to Phuliani to Rakhni to Rarkhan (Ranrkan; Rarkan) to Kingri to west of Musakhel bazaar town. Its relative movement is about $2-3 \mathrm{~km}$ at Chaper bend which is decreasing northward and also southward. It hits many formations of Mesozoic and Cenozoic age. Its relative movement shows left lateral strike slip fault (Figure 6).

Daragal-Phailawagh strike slip fault is trending generally north east-south west (Figure 6). It hits Pab, Vitakri, Rakhi Gaj, Dungan and Shaheed Ghat formations. It also seems to be left lateral strike slip fault.

\subsection{Geological History and Depositional Environments of Sediments of Mari Bugti Hills and Surroundings, Balochistan and South Punjab, Pakistan}

The sediments exposed in the Mari Bugti and surrounding areas ranges in age from Triassic to Recent. Triassic Wulgai and Jurassic Loralai and Chiltan Formations of Sulaiman Group were deposited under the marine environments. The fine clastic materials of Wulgai and other formations of Sulaiman Group seem to be derived from the east (western part of Indo-Pakistan shield). The marine carbonate of Loralai and Chiltan formations were deposited under Tethys marine conditions. The Jurassic-Cretaceous boundary was marked by lateritic to ferruginous strata of lacustrine origin. The Sembar, Mekhtar, Goru and Parh formations of Early Cretaceous Parh Group was deposited under marine conditions. The Mughalkot, Fort Munro, Pab and Vitakri formations of Late Cretaceous Fort Munro Group represent both marine and terrestrial environments. The Sangiali, Rakhi Gaj and Dungan formations of Paleocene Sangiali group represent also marine conditions. The clastic materials of Parh, Fort Munro and Sangiali groups were derived from the east. The clastic materials of Early Eocene Chamalang Group of study area derived from northwest and north (instead of east). The Latest Paleocene or Earliest Eocene is the turning point for the derivation of clastic materials. At this time the Paleo Vitakri River System declined and Paleo Indus River System birth occurred due to uplift of northwestern and northern areas by tectonic collision of Indo-Pakistan continental plate with Asian continental plate. This collision sandwiched some subduction of Tethys belts. The Shaheed Ghat, Toi, Kingri, Drug and Baska formations of Chamalang Group show marine, deltaic, evaporitic and terrestrial environments. Kahan Group (Habib Rahi, Domanda, Pirkoh and Drazinda formations which were previously members of Kirthar Formation) was deposited under marine conditions. The clastic materials of Kahan Group derived from north. After this the main episode of convergence of Indo-Pakistan plate with Asian plate occurred which is responsible for the uplifting, folding and faulting. The Oligocene-Pliocene Vihowa group (Chitarwata, Vihowa, Litra and Chaudhwan for- 
mations) and Pleistocene-Holocene Sakhi Sarwar Group represent the continental mollasse conditions derived from the uplifted areas of Hindukush and Himalayas. The Subrecent and Recent deposits show the alluvium with minor colluvium and eolian.

\subsection{Economic Geology of Mari Bugti Hills and Surrounding Areas, Balochistan and South Punjab, Pakistan}

Many mineralizations are reported from the area.

Huge gypsum and cement raw material resources: The huge and vast deposits of gypsum and cement raw materials are found in Mari Bugti hills and surroundings but no anyone cement industry is installed here. All the syncline north of last exposed trend of Drug rubbly limestone (Figure 5) host huge gypsum along with cement resources. Dera Bugti town-Pirkoh section (Figure 5), Kohlu and Barkhan areas have feasible and best sites for cement industry installation because of huge occurrences of all raw materials for cement industry [7] [8] [50]-[57].

Coalfields: The coal producing coalfileds are Mach, Abe Gum, Marwar, Deghari-Sor Range, Khost-Shahrig-Harnai, Duki-Anambar and Chamalang-Lunda. The Surghari, Nosham and Bahlol areas show thin coal seams. Kingri area also represents muddy and lignitic coal with laminated quartzose sandstone [7] [8] [58]-[63].

Petroleum Resources: The southern part (Sui, Uch, Loti, Pirkoh) of Bugti hills and Dhodhak oilfield in Taunsa area of D. G. Khan district yielding significant petroleum. Drilling in some localities in Musa Khel (Savi Ragha Drug), Barkhan (Jandran) and Kohlu districts yielded promising results. Recently petroleum exploration started in Kohlu, Barkhan, Musa Khel, Rajan Pur and D. G. Khan districts which may yield better results. Some petroleum seeps like Khatan (Figures 3-5), Mawand (Figure 5) and Mat Khetran (Figure 5) areas; water gas springs in Kinwa Vitakri area (Figure 5) were also reported. There are many promising resource rocks for petroleum are shales of Sulaiman Group, Sembar, Goru, Mughal Kot, Rakhi Gaj and Eocene shales (Figure 1), reserve rocks for petroleum are limestones of Sulaiman Group, sandstones of Mekhtar and Goru, limestones of Parh, sandstone of Mughal Kot, Pab and Rakhi Gaj formations and limestones and sandstones of Eocene strata and possibly sandstones of Oligocene to Pliocene Vihowa Group (Figure 1) and best anticlinal structures for the exploration and drillings of petroleum resources (Figures 2-7) in the Mari Bugti hills and surrounding areas.

Water Resources: The valley areas of Mari Bugti hills include the Eocene shales which are partly exposed and partly covered by thin cover of Subrecent and recent alluvium or rarely eolian. The perennial streams yield also brackish and saline water. The Eocene shale makes water brackish and further gypsum beds of Baska and also Domanda formation plays more role to make water brackish. Fresh water springs are rare in bed rocks like limestones, marl and 
sandstones. Government facilities for fresh water supply are also rare, partly due to disperse houses. Mostly due to thin alluvium cover on bed rock, the fresh water is also minor to small. Most of the dispersed population of Mari Bugti areas use small mud dam for drinking water. During scarcity of rain they use brackish saline water [7] [8] [58]. Consequently the medium and small dams (as mentioned in recommendations) are urgent for drinking and cultivations which can play major role for the development of the Mari Bugti areas and consequently for Balochistan and Pakistan. I again request from authority to construct small dams for dispersed local population of Mari Bugti hills. Rare water springs in limestone and sandstones are fresh and mostly away from jhugi or homes. Further the disperse population of Mari Bugti tribes need assistance for construction of mud and brick houses to replace jhugi. Jhugi is arc type room made of wood. The hot water springs in the Mahiwal and Karu of Loralai district and Zinda Pir and Garmaf localities of Taunsa area of D.G.Khan district were also reported [7] [8] [58].

Fluorite deposits: Significant fluorite deposits (50,000 tons) were reported in the northern extremity of the study areas like Gadebar, Daman Ghar, tor Thana, Wategam, Mekhtar, Balao, Mahiwal areas of Loralai District, Balochistan [64] [65] [66]. The fluorite occurs as veins in the Jurassic Loralai limestones.

Celestite deposits and showings: Small deposits and showings of celestite are found in the Mari Bugti hills and northern extremity areas [8] [67]. Celestite deposits reported in the Early Eocene Drug Formation of the Lal Khan (Figure 2), Lakha Kach (Figure 2, Gadumra (Figure 2) and Bahlol areas of Barkhan, Sham (Sardar Wadera Shero Bugti Sham) (Figure 5), and Pirkoh areas of Dera Bugti, Chamalang areas of Kohlu and Toi Nala areas of Musa Khel districts, Balochistan.

Diversified Clay deposits: Significant clay deposits (fuller earths and others) are reported in the Kahan, Chamalang and Vihowa groups and alluvial flood plain deposits of Dera Bugti, Rajan Pur, D.G.Khan, Musakhel-D.I.Khan, Barkhan and Kohlu districts [7] [8] [68]. Huge reserves of fuller's earth are observed in Domanda, Drazinda and Baska formations in eastern Mari Bugti hills and surroundings. The clay deposits upto easily mineable depths 200 meters were estimated about 1 billion ton from eastern Sulaiman foldbelt. The clay was estimated 10 million tons upto 200 meter easily mineable depth in Zinda Pir anticline areas [68].

Barite deposits: Small barite deposit was reported in the Sembar shale of Mekhtar and surrounding areas [7] [8] [69].

Iron and ochre deposits: Low grade iron deposits from Fort Munro and surroundings were reported in Rakhi Gaj sandy ferruginous beds, and high grade iron deposits (very small) from Rakhi Gaj to Barthi areas and iron stone from Dera Bugti (Figure 5) were found in Chitarwata Formation [7] [8] [53]. Small deposits of red ochre are found in different formations and different parts especially the southwestern part of Kohlu syncline [7] [8] [53]. 
Construction and other resources: Large deposits of limestones (marbles), marl, dimension stones and construction materials like limestone and sandstones were reported in the Mari Bugti hills and surroundings [54]. Marble being developed from Kasa and Karu areas of Loralai, and construction materials being produced from Sakhi Sarwar and Taunsa areas of Dera Ghazi Khan. Agrominerals [54] [70], iron, ocher and industrial minerals and other commodities [7] [8] [71] [72], uranium and other radioactive minerals [73], silica sands [7] [8], silica sand from Chitarwata Formation of Dera Bugti (Figure 5), quartzite/quartzose sandstone, gemstones and jewelry resources especially chert and jasper and others from older rocks and also from placer mollase Vihowa Group and rarely copper minerals were also reported from Mari Bugti hills and surroundings [7] [8] [54]. Paleontological discoveries and further explorations in the Mari Bugti hills and surroundings attract foreign researcher and play role for development of area and economic significance.

\subsection{Paleontology of Mari Bugti Hills and Surrounding Areas, Balochistan and South Punjab, Pakistan}

Mari Bugti hills and surroundings are rich in Mesozoic and Cenozoic vertebrate and invertebrate fossils. Previously many workers reported many diverse invertebrates [1] [2] [3] [43] [46] [47] [49]. Recently a nautiloid Pakiwheel vitakri [31] [32] [74] and centipedes arthropods Nisaukankoil and Phailawaghkankoil [31] [32] were reported along with many other invertebrates like gastropods, pelecypods, foraminifers, etc. Further study area yielded famous vertebrates like diverse and significant bone fossils and ichnotaxa of Mesozoic archosaurs, Cretaceous large tree, and fossil bones of largest rhinoceroses, walking and swimming whales from Cenozoic strata. The latest Cretaceous archosaurs from middle Indus/Sulaiman basin of Pakistan were found from Vitakri dome, Mari Bohri, Dhaola-Andari-Chapar, Pikal, Fort Munro-Maarri and Mianghundi anticlines (Figure 5) (Figure 6). These structures and surroundings areas in Indus basin significant for further exploration of bone fossils, ichnofossils and eggs, and also for fine sediments teeth and bones of biota (by sediments washing and screening methods).

\subsubsection{Poripuchian Titanosaurs and Other Biotas from the Mesozoic of Mari Bugti Hills and Surroundings, Balochistan and South Punjab, Pakistan}

Poripuchian titanosaurian sauropods from the Latest Cretaceous Vitakri Formation of Pakistan: From India dinosaurs discovered since about 2 centuries ago [75] but from Pakistan dinosaur discovered recently about 2 decades of years (since 2000) [32] [42] [76] [77] [78]. All the Indian latest Cretaceous titanosaurs are unofficial and informal except Isisaurus while all Pakistani latest Cretaceous titanosaurs are formal and official [32] [42] [79]. Nine titanosaur genera were reported from the Latest Maastrichtian (67 - $66 \mathrm{Ma}$ ) Vitakri Formation of Fort Munro Group found in Barkhan district of Balochistan Province, 
Pakistan. Before August 2021 all of Pakistani titanosaurs were informal. Among these Gspsaurus, Saraikimasoom Pakisaurus, Sulaimanisaurus and Khetranisaurus were formally described in August 2021 [42] and other four titanosaur taxa like Balochisaurus, Nicksaurus Marisaurus and Maojandino were formally described in September 2021 [32]. Recently found titanosaur materials from Pakistan are considerably more than the titanosaur materials reported from India since round about 2 centuries ago. Some Pakistani titanosaurs consist of cranial and postcranial associated skeletons (Figure 8) while some have vertebral and appendicular associated assemblages. Further most of Pakistani titanosaurs show overlapping holotypic bones with each other which provide the best opportunity for correlation and comparison among each other and coeval titanosaurian sauropods from India and also from global world. Titanosaurian osteoderms and armor bones reported from Pakistan in 2003 which were first reported from Asia and also Indo-Pakistan subcontinent [80]. Later these were assigned to species level [32] [41] [42] [76] [77] [81] [82].

Poripuchia is a clade of titanosaurs includes all tail procoelous vertebrae including distalmost procoelous caudals while lithostrotians have no distalmost procoelous caudals. From South Asia especially from Pakistan, some titanosaurian sauropods have distalmost procoelous caudals while others have not assigned distal caudals. Gspsaurus, Balochisaurus, Marisaurus, Pakisaurus and Isisaurus have yielded distalmost procoelous caudals and assigned as members of Poripuchian titanosaurs.

Titanosaurian sauropods from South Asia are divided into Pakisauridae, Balochisauridae and Gspsauridae. Pakisauridae represents the titanosaurs which have caudals with no ventral reduction like Pakisaurus, Sulaimanisaurus, Isisaurus and Khetranisaurus. Balochisauridae represents the titanosaurs which have caudals with ventral reduction and first biconvex caudals like Balochisaurus and Marisaurus. Gspsauridae is based on snout, mandible and dentition morphology. It is further subdivided into Gspsaurinae which have V-shaped lower teeth row like Gspsaurus, and Saraikimasoominae which have U-shaped lower teeth row like Saraikimasoom.

Gspsaurus (Gspsaurinae, Gspsauridae, Poripuchia) holotypic skeleton from Alam is represented by snout and adjoining skull elements, braincase, cervical, dorsal and caudal vertebrae, sternal/ilia, left and right scapulae, radius, left femur, left and right tibiae [42] [76]. Gspsaurus is represented by combination of diagnostic features like V-shaped teeth row converged anteriorly (Figure 8), conical and long teeth (not closely contact but slightly spaced especially the mid of row); large sized snout (Figure 8) than Saraikimasoom; slightly spaced teeth; broad and constricted occipital condyle with decurved and much taller Paroccipital processes of braincase; slightly tall caudals with ventral reduction but less than ventral reduction of caudals of Balochisaurus, relatively more transversely expanded proximal tibia (biconvex lense shaped with slightly more anteroposterior width than transverse width) than Pakisaurus and Sulaimanisaurus but less than Balochisaurus; and distal tibia is transversely broad with parallelogram 

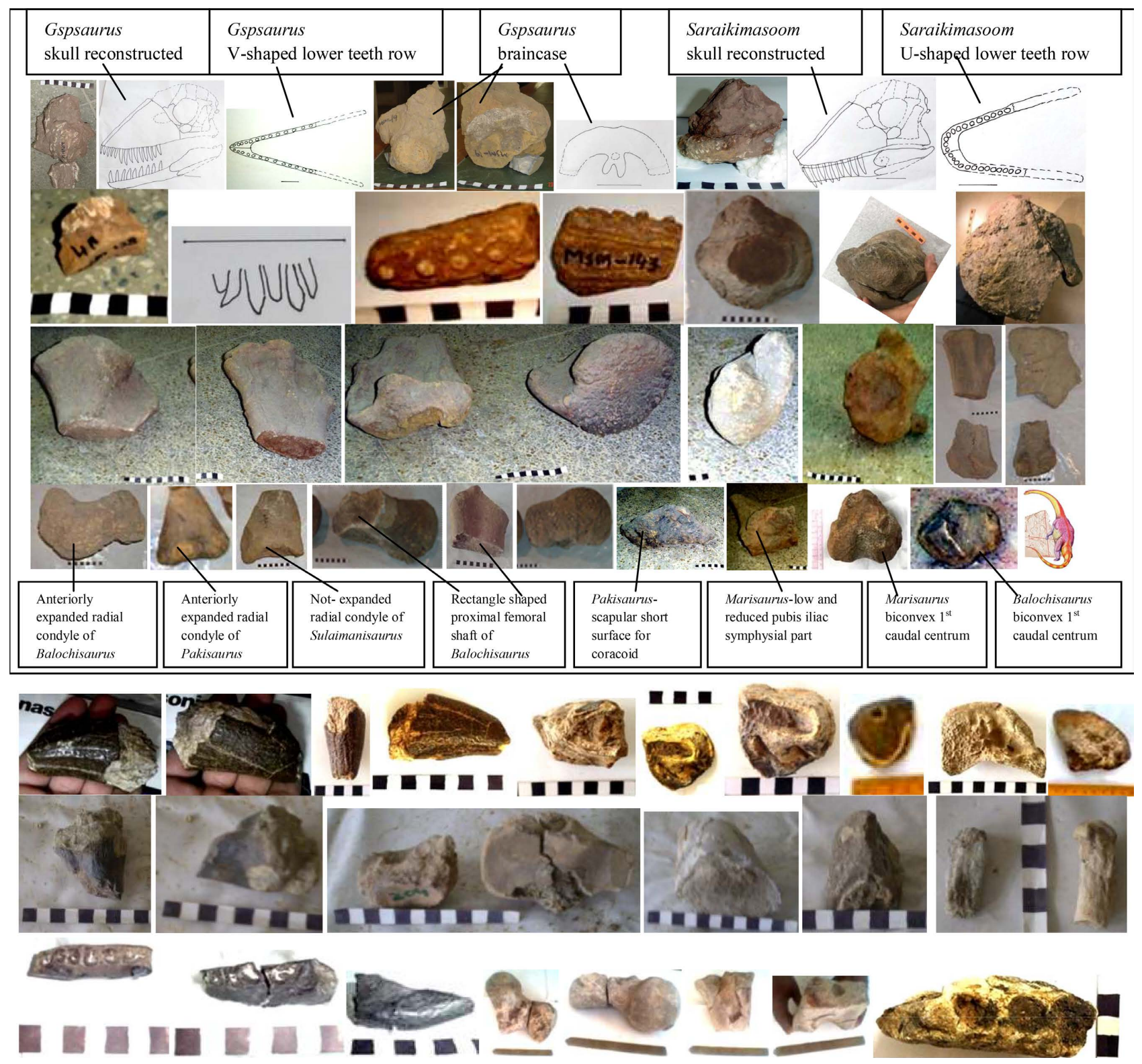

Figure 8. Row 1, photo/p1, Gspsaurus skull; p2, Gspsaurus skull reconstructed; p3, Gspsaurus V-shaped lower teeth row; p4,5,6, Gspsaurus braincase and its line drawing in posterior view, p7, Saraikimasoom skull; p8, Saraikimasoom skull reconstructed; p9, Saraikimasoom U-shaped lower teeth row. Row 2, p1,2, Nicksaurus closely contacted articulated teeth; p3,4, Pakisaurus widely separated teeth; p5-7, Balochisaurus tilted sub-rectangle shaped proximal tibia. Row 3, p1, Gspsaurus lense shaped proximal tibia; p2, Pakisaurus proximal flat tibia; p3, comparison of proximal tibiae of Pakisaurus and Gspsaurus, p4,5, oval or parallelogram rectangle shaped distal tibiae of Balochisaurus and Gspsaurus respectively; p6, flat tibia of Pakisaurus; p7, flat tibia of Sulaimanisaurus. Row 4, p1, Balochisaurus humerus with anteriorly expanded radial condyle; p2, Pakisaurus humerus with anteriorly expanded radial condyle; p3, Sulaimanisaurus humerus non-expanded radial condyle; p4,5, Balochisaurus proximal femora with rectangular cross section; p6, Balochisaurus femur with expanded head; p7, Pakisaurus distal scapula with short surface for coracoid articulation; p8, Marisaurus pubis with low and reduced pubis iliac symphysial part; p9, Marisaurus biconvex first caudal; p10, Balochisaurus biconvex first caudal; p11, Balochisaurus model. Row 5, Some fossils of Buzdartherium gulkirao Paraceratheriinae Paraceratheriidae rhinoceros, scale in 2 images of tusk like teeth, in 2 images yellow scale with each cm digit, and for others each black or white digit is $1 \mathrm{~cm}$. Row 6, Some fossils of Pakitherium shagalai Paraceratheriinae Paraceratheriidae rhinoceros. Row 7, p1-3, dentary of Bolanicyon shahani horse or paleodog; p4-7, some fossils of Gomphotherium buzdari proboscidean; p8, jaw of Asifcroco retrai eucrocodile. Scale, each black or white digit is $1 \mathrm{~cm}$. For G. buzdari, total scale is $26 \mathrm{~cm}$. Scale bar in line drawings represent $5 \mathrm{~cm}$. 
rectangle shaped or oval shaped trending transversely while Pakisaurus and Sulaimanisaurus have anteroposteriorly broad distal tibia (Figure 8). Gspsaurus is stocky poripuchian titanosaur and stable for phylogenetic analyses [42].

Maojandino (Gspsaurinae, Gspsauridae, Poripuchia) holotypic skeleton from Alam is represented by braincase, cervical, dorsal and caudal vertebrae, sternal/ilia, left and right scapulae, radius, left femur, left and right tibiae [32] [76]. Maojandino is represented by combination of diagnostic features like slightly tall caudals with ventral reduction but less than ventral reduction of caudals of Balochisaurus, relatively more transversely expanded proximal tibia (biconvex lense shaped with slightly more anteroposterior width than transverse width) than Pakisaurus and Sulaimanisaurus but less than Balochisaurus, distal tibia is transversely broad with parallelogram rectangle shaped or oval shaped trending transversely while Pakisaurus and Sulaimanisaurus have anteroposteriorly broad distal tibia. Maojandino holotype is also the major part of Gspsaurus holotype, as a result Maojandino is being considered junior synonym of Gspsaurus.

Saraikimasoom (Saraikimasoominae, Gspsauridae) holotypic snout was found from south Kinwa. Saraikimasoom holotype has key features like U-shaped lower teeth row (Figure 8) (while Gspsaurus has V-shaped lower teeth row); conical slender teeth gradually decreasing width toward tip (except tip); teeth closely contact with each other while Gspsaurus has spaced teeth (not closely contacted with each other especially mid of teeth row); and relatively small sized skull than Gspsaurus skull [42] [77]. Saraikimasoom snout has fracture on anterodorsal part (Figure 8) providing clue of subterminal nare of titanosaur or crocodile, it will be confirmed by internal scanning.

Nicksaurus (Saraikimasoominae, Gspsauridae) holotypic skeleton from north Kinwa is represented by jaw with articulated teeth, cranial fragments, cervical, dorsal and caudal vertebrae, chevron, humerus, radius, left and right femora, left and right tibiae [32] [77]. Nicksaurus is represented by combination of diagnostic features like medium sized slender teeth closely contacted with each other like Saraikimasoom and unlike Gspsaurus which have spaced teeth and Pakisaurus which have more widely spaced teeth in jaw (Figure 8), broad caudals unlike Balochisaurus which have almost squarish caudals, caudals with strong ventral reduction like Balochisaurus and unlike Gspsaurus which have relatively less ventral reduction of caudals, Pakisaurus and Sulaimanisaurus represent almost no ventral reduction or slight ventral reduction, and Khetranisaurus represents almost slight ventral expansion (instead of reduction); and distal tibia is transversely broad with oval shaped trending transversely like Gspsaurus, while Pakisaurus and Sulaimanisaurus have anteroposteriorly broad distal tibia (Figure 8). Possibly associated materials from South Zubra [77] like two caudal vertebrae GSP/MSM-523-7 and GSP/MSM-524-7 (broad and ventrally reduced), right mid scapula GSP/MSM-746-7 and large oval ellipsoidal osteodermal/armor plate GSP/MSM-84-7 are referable to Nicksaurus razashahi. Nicksaurus is included in 
Saraikimasoominae gspsaurid due to close matching of closely contacted teeth and moderate teeth size.

Balochisaurus (Balochisauridae, Poripuchia) holotypic skeleton from southern Mari Bohri is represented by cervical, dorsal and caudal vertebrae including first biconvex caudal and trirays distalmost caudal, ribs, neural spine, left humerus, left ulna, metacarpal, left acetabulum, left femur and left tibia [32] [77]. Balochisaurus has holotypic key features like squarish caudals (while Nicksaurus has broad caudals) with strong ventral reduction (more than the ventral reduction of caudals of Gspsaurus and Marisaurus); rectangle shaped cross section of proximal femoral shaft; it has strongly transversely expanded proximal tibia (tilted subsquare or tilted rectangle shaped with equal transverse and anteroposterior width), while Pakisaurus and Sulaimanisaurus has flat proximal tibia, and Gspsaurus has lense shaped proximal tibia. The assemblage from Grut locality like caudal vertebrae GSP/MSM-52-9 and GSP/MSM-793-9, stocky distal tibia GSP/MSM-75-9, right astragalus GSP/MSM-752-9 (transverse length $15 \mathrm{~cm}$, anteroposterior width $10 \mathrm{~cm}$ ), distal ulna GSP/MSM-252-9, proximal humerus with prominent head (mosaic of samples GSP/MSM-694-9 and GSP/MSM-759-9). It's referred distal tibia from Grut locality is transversely broad with parallelogram rectangle shaped or oval shaped trending transversely like Gspsaurus and Nicksaurus, while Pakisaurus and Sulaimanisaurus have anteroposteriorly broad distal tibia (Figure 8). The mid Sangiali vertebral and appendicular assemblage [76] is surely referable to Balochisaurus malkani. The stockiest tilted subsquare/rectangle shaped proximal tibia and reduced mid caudal vertebrae of mid Sangiali assemblage perfectly match with the holotypic relevant bones of Balochisaurus malka$n i$ from Mari Bohri locality. Consequently mid Sangiali assemblage of Balochisaurus malkani is consistent with its holotypic vertebral and appendicular materials.

Marisaurus (Balochisauridae) holotypic skeleton found from north Mari Bohri is represented by caudal vertebrae including first biconvex caudal and trirays distal caudal, scapula, pubis and femur [32] [76]. It is characterised as slight ventral reduction of caudals like Gspsaurus while Balochisaurus and Nicksaurus have strong reduction of caudals, Pakisaurus, Sulaimanisaurus and Khetranisaurus have no significant ventral reduction of caudals; its ball like biconvex first caudal while Balochisaurus has broad first biconvex caudal; pubis iliac symphysial part is low and reduced, while the Isisaurus has elevated iliac symphysial; proximal pubis has wide and thick glenoid; and scapular short articular surface for coracoid articulation. Marisaurus bears no restricted articular posterior ball in caudals while Gspsaurus bears restricted articular posterior ball in caudals. Marisaurus is included in Balochisauridae due to overlapping of biconvex first caudal with Balochisaurus.

Pakisaurus (Pakisauridae, Poripuchia) holotypic skeleton found from south Kinwa is represented by cervicodorsal, presacral, sacral and caudal vertebrae, left and right scapulae, sternal, humerus, left and right ulnae, radius, metacarpal, ilia, 
right femur and left fibula [41] [42]. Pakisaurus is represented by combination of diagnostic features like tall caudals without ventral reduction (while Gspsaurus, Marisaurus, Balochisaurus and Nicksaurus represent ventral reduction, Sulaimanisaurus have squarish caudal with no ventral reduction and Khetranisaurus have ventral expansion of caudals), humerus with expanded radial condyle anteriorly, flat proximal tibia and anteroposteriorly broad distal tibia (relatively more anteroposteriorly broader distal tibia than the distal tibia of Sulaimanisaurus) (Figure 8). Pakisaurus is slender poripuchian titanosaur and it is stable and can be used for phylogenetic analyses [42].

Sulaimanisaurus (Pakisauridae, Poripuchia) has holotypic seven caudal vertebrae and referred humerus, femur, tibia, fibula and metatarsal [42]. This material is diagnostic. It is represented by a combination of features like squarish caudal with no or negligible ventral reduction, humerus without expanded radial condyle anteriorly and flat transversely compressed proximal tibia and anteroposteriorly broad distal tibia (relatively less broad anteroposteriorly than distal tibia of Pakisaurus).

Khetranisaurus (Pakisauridae) has holotypic two caudal vertebrae [42] but unique feature among Indo-Pakistani titanosaurs is the broad ventral width of caudal than width of dorsal view of caudals.

Theropod dinosaurs from Pakistan: Two theropods like Vitakridrinda and Vitakrisaurus are known from Pakistan so far.

Vitakridrinda (Vitakrisauridae) holotypic fossils according to original formal publication [42] as per ICZN rules are more than 10 teeth, a pair of femora and a pair of dorsal vertebrae, and referred dorsal and caudal vertebrae and a few metapodials [42]. Vitakridrinda has short and broad oval teeth (like Indosuchus raptorius), subcircular teeth (while Vitakrisaurus and Indosuchus have oval shaped teeth convexing lingually and labially), teardrop type teeth (like Rahiolisaurus); proximal femoral shaft with slightly transversely broad with thick peripheral bone enveloped on the central hollow cavity while distal shaft is more broader; its femoral anterior trochanter is vertically oriented and blunted at tip; its ventrally broad centra (without ventral keel like Vitakrisaurus) having ventral smooth plain and forming reduced neck at the dorsal portion which also differentiates it from the, Rajasaurus and Rahiolisaurus both have dominant ventral keel on dorsal centra [42] [78]. Vitakridrinda have elongated, tall and ventrally expanded dorsal vertebrae while Vitakrisaurus have elongated cylindrical dorsal vertebrae and Rajasaurus have short and tall dorsal vertebrae. Vitakridrinda have elongated and square shaped to cylindrical caudal vertebrae while Vitakrisaurus have elongated and tall caudal vertebrae. Vitakridrinda did not have ventral keel in dorsal and also caudal centra, while Rajasaurus and Rahiolisaurus have ventral keel on dorsal and caudal centra. Vitakridrinda neural canal is dorsoventrally tall suboval shaped in anterior caudal vertebrae while Vitakrisaurus neural canal is dorsoventrally compressed, transversely oval shaped in anterior caudal and also in middle caudal vertebrae. Vitakridrinda have amphicoelous 
biconcave caudal vertebrae, while Rajasaurus and Rahiolisaurus have amphiplatyan or flat articular surfaces or feeble amphicoely. Distal caudal is anteroposteriorly elongated subcylinder type with long parallel ridges alternated by long grooves on all sides, except the anterior and posterior concave articular surfaces. This distal centrum has no apparent neural arch connection.

Vitakrisaurus (Vitakrisauridae) holotypic fossils according to original formal publication [42] as per ICZN rules are a manus, ulna, caudal vertebrae and a few limb bones, and referred anterior dentary symphysis, dentary ramus with articulated teeth, dorsal vertebra and a few limb bones from Pakistan [42] and an amphicoelous vertebra with small sized chevron from India [42]. Vitakrisaurus has weak anterior articulation of thick and deep dentary rami with external pitted and lineated structures; V-shaped anteriormost end of dentary symphysis (blunted as w-shaped) while Rahiolisaurus anterior jaw ramus shows curvature representing U-shaped anterior symphysis [42] [78]. Further distinguishing features are shown as above with Vitakridrinda.

Mesoeucrocodiles from the Latest Cretaceous Vitakri Formation of Pakistan: Five mesoeucrocodiles are known from Pakistan. Pabwehshi and Induszalim (Induszalimidae represents deep rostrum) have deep rostrum but terminal and subterminal nares respectively [42]. Sulaimanisuchus (Sulaimanisuchidae estimated from anterior mandibles as moderate deep and broad rostrum) have enlarged fourth dentary tooth which is differentiated from small fourth dentary tooth of Pabwehshi [42]. Mithasaraikistan ikniazi (Mithasaraikistanidae represents broad rostrum) has transversely wide snout [42] while Pabwehshi and Induszalim have deep snout [42]. Teeth size and orientation differentiate these from others. Khuzdarcroco was based on a partial slender rib [32].

Snake from the Latest Cretaceous Vitakri Formation of Pakistan: Wadanaang with slender and straight teeth only recurved on tip [32] [42] differed from the stocky and low angle arc shaped teeth of Sanajeh. Wadanaang precloacal vertebra has ventral keel and relatively broader neural canal.

Pterosaur from the Latest Cretaceous Vitakri Formation of Pakistan: Toothed Pterosaur Saraikisaurus based on slender and pneumatic lower beak with partially overlapped oval teeth [42].

Bird from the Latest Cretaceous Vitakri Formation of Pakistan: Wasaibpanchi is the first Cretaceous bird in Indo-Pakistan subcontinent which has asymmetric heterodont trigonal and triconvex relatively less transversely compressed teeth (with broad base and asymmetric anterior and distal ends) while Archaeopteryx, Hesperornis and Ichthyornis have flattened and transversely more compressed teeth. Wasaibpanchi bore long conical teeth while Pengornis bore short blunted teeth to eat arthropods. Wasaibpanchi bore relatively less transversely compressed large teeth while bohaiornithids enantiornitheans bore strongly transversely compressed large, robust and somewhat conical teeth. Wasaibpanchi bore long teeth while Gobipteryx has no teeth. Wasaibpanchi has larger teeth cavity which is enveloped by blue thin enamel layer and then outer 
thin white enamel layer, while Archaeopteryx has flattened enamel crown set upon a wider semi elliptical bony base, and theropods and mesoeucrocodiles from Pakistan have relatively thick enamel on short core cavity. The Wadanaang snake and Wasaibpanchi bird (possibly with Induszalim mesoeucrocodile and Vitakridrinda theropod) were preying on the egg (possibly egg nesting) of Gspsaurus titanosaurian sauropod and also its carcass [32] [42].

Archosaurs footprints and trackways from Mesozoic of Pakistan: A natural cast of titanosaurian sauropod Sauropaonia Dgkhansauroperus maarri [32] (=Dgkhansaurus maarri [31]) was reported from the latest Cretaceous Pab sandstone of Maarri peak area of Rajanpur district, South Punjab [83]. A pes of sauropod Sauropaonia Chiltansauroperus nicki [32] (=Chiltanpaer nicki [42]) was reported from the latest Jurassic Chiltan Limestone of Kharzan Moola area of Khuzdar district, Balochistan. A few partial trackways of Ornithischian or titanosaurian sauropods Ornithopaonia Pashtosauroperus zhobi [32] (=Pashtosaurus zhobi [74]) was reported from the latest Cretaceous Vitakri Formation of Qila Saifullah district, Zhob Division, Balochistan. A few partial trackways of titanosaurian sauropods or ornithischian Ornithopaonia Malakhelisauroperus mianwali [32] (=Malasaurus mianwali [84]; Malakhelisaurus mianwali [81]) was reported from the latest Jurassic Samana Suk limestones of Mianwali district, Punjab. A few partial trackways of pterosaurs (flying reptiles) Pteropaonia Anmolpakhiperus alleni [32] (=Anmolpakhi alleni [31]) was reported from the latest Cretaceous Vitakri Formation of Qila Saifullah district, Zhob Division, Balochistan [31] and also a partial trackway reported from the latest Jurassic Samana Suk limestones of Moharian area, Khoshab district, Punjab. A trackway of large theropod abelisaurian Theropaonia Samanadrindoperus surghari [32] (=Samanadrinda surghari [84]) and two adjoining trackways of small theropod noasaurian Theropaonia Himalayadrindoperus potwari [32] (=Himalayadrinda potwari [31] [74]) were reported from the latest Jurassic Samana Suk limestones of Malakhel area of Mianwali district, Punjab. A trackway of large theropod abelisaurian Theropaonia Samanadrindoperus surghari [32] confronted on a herd of herbivorous sauropaonian dinosaurs Malakhelisauroperus.

Kahamachli Caturidae fish from the late Cretaceous of Pakistan: A partial skeleton of Kahamachli harrandlundi Caturidae fish was reported [31] [32] from the upper part of late Cretaceous Pab Formation of Kaha Harrand area (just northeast of Maarri peak). This fish is found on the eastern limb of Fort Munro-Maarri anticline.

Baradarakht goeswangai a large tree from the late Cretaceous of Pakistan: A large petrified stem stem of Baradarakht goeswangai was reported from late Cretaceous Dhaola member of Pab Formation of Fort Munro Group of Goeswanga pass (near east of Nahar Kot) of Barkhan district, Balochistan [31] [32] [74]. Preserved wood is $24 \mathrm{~cm}$ long with $20 \mathrm{~cm}$ diameter. It is a soft wood which indicating its assignment to gymnosperms. This petrified wood stem is fibrous showing its assignment to angiosperms or it may bay be phloem and xylem of 
gymnosperms.

\subsubsection{Largest land Mammals and Other Vertebrates from the Cenozoic of Mari Bugti Hills and Surroundings, Balochistan and South Punjab, Pakistan}

The first time vertebrates like mastodon, hippopotamus, partial jaws and bones of crocodiles from Bugti hills were reported by [85]. He reported the richness of fossils like that many cart loads of bones can be collected from an acre land in the Late Tertiary terrestrial strata of Khumbi and Dera Bugti areas. Later Tertiary fossils were reported from the Bugti areas by [38] [86] [87] [88]. Paraceratherium (syn; Baluchitherium, Indricotherium) Paraceratheriinae Paraceratheriidae Perissodactyla largest land mammal was reported from Bugti area [88]. Some fossils referred to Bugtitherium grandincisivum by [89]. The Vihowa Group represents a unique blend of mammals of Asian affinity. It includes Paraceratheriids, rhinoceroses and antharacotherids with few proboscideans, carnivores, chalicotheres, suids and crocodilians [4] [89] [90].

Recently Buzdartherium gulkirao (Figure 8) a large Paraceratheriinae Paraceratheriidae Perissodactyla rhinoceros was discovered during 2014 and reported from the Oligocene Chitarwata Formation of Gulki Taunsa section of eastern Sulaiman foldbelt of South Punjab [31] [32] and Pakitherium shagalai (with its fetus) a large Paraceratheriinae Paraceratheriidae Perissodactyla rhinoceros (Figure 8) which was discovered during 2013 and reported from the Eocene Shagala Formation of Shagala type locality of northern Balochistan basin and northern Balochistan province of Pakistan [31] [32] [91]. The referred limb elements of Buzdartherium gulkirao collected (during 2014) and hosted by Rao M. Ayub (resident of Gujranwala) of Pakistan Atomic Energy Commission, Taunsa (Dera Ghazi Khan) [32]. Further Asifcroco retrai terrestrial eucrocodile (Figure 8) was discovered during 2014 from the terrestrial Oligocene Chitarwata Formation [31] [32] in the Gulki Taunsa section (same type locality as Buzdartherium gulkirao) and Gomphotherium buzdari (Figure 8) collected during 2014 from terrestrial Litra Formation of Vihowa Group [31] [32] of Mahoi area of Taunsa. Eocene Walking whale [92] from Rakhni area and swimming whale [91] from Zamri (Drug, Musa Khel) area were also reported from the northern surrounding of study area.

\subsubsection{Recently Discovered Flora and Fauna from Pakistan}

Recent paleontological exploration during 2000-2022 has shown 51 new taxa of biotas from Pakistan. Among these 1 bone taxa of titanosauriform (Brohisaurus kirthari), 11 bone skeleton taxa and 2 ichnotaxa of titanosaurian sauropods, 2 ichnotaxa of ornithischian or titanosaurian sauropods like Malakhelisauroperus and Pashtosauroperus, 2 bone taxa and 2 ichnotaxa of theropods, 6 taxa of crocodiles, 1 bone taxon and 1 ichnotaxon of pterosaur (flying reptiles), 1 taxon of snake, 1 taxon of bird, 1 taxon of plesiosaur (marine reptile), 3 taxa of fishes, 9 taxa of mammals, 7 taxa of invertebrates and 1 taxon of tree plant were reported [32] [42]. Most of these taxa are mentioned above, some are being mentioned 
below. Besides nine titanosaur taxa as shown above, the Malkanisaurus balochi (after the Malkani tribe and Baloch tribe respectively) which is the synonym of Balochisaurus malkani (after the Baloch and Malkani tribes) and Anokhadino mirliaquati (after the Mir Liaquat Mari son of Maojan Mari and Mir Muhammad Khetran of Vitakri) which is the synonym of Pakisaurus balochistani (honoring the host country Pakistan and host province Balochistan) were also reported. Anokhadino mirliaquati was based on cranial and postcranial skeleton reported from lower Bor locality. Later on Anokhadino mirliaquati assemblage was referred to Pakisaurus balochistani on the overlapping of vertebral and limb elements matching shapes and features. Besides Kahamachli harrandlundi which is mentioned as above, the other 2 taxa of fishes like Muzaffarabadmachli abbottabadi from Cambrian dolomitic limestone of Abbottabad Formation of Muzaffarabad, Azad Kashmir and Karkhimachli sangiali from Cretaceous-Paleogene boundary strata of Karkh area of Khuzdar district, Balochistan were reported [32]. Further a marine reptile plesiosaur Zahrisaurus kilmoolai from Jurassic Chiltan limestone of Kil locality and a Sirenian Kilgai moolakharzani from Eocene Shaheed Ghat shale of Kil locality of Moola Kharzan area of Khuzdar district, invertebrates centipedes Nisaukankoil beakeri and Phailawaghkankoil derabugti from the Early Paleocene Sangiali Formation of boarder area of Nisau (Kohlu district) and Beaker and Phailawagh (Dera Bugti district), the starfish Mulastar zahri from Early Eocene Shaheed Ghat shale of southeastern Kharzan area, the bivalve Pakiring kharzani from the latest Cretaceous Vitakri Formation of north Kharzan area, and the nautiloids Pakiwheel karkhi and Pakiwheel vitakri were reported from the early Paleocene Sangiali Formation of Karkh (Khuzdar) and Vitakri (Barkhan district), Balochistan were reported [32]. The significant mammals whales, Artiocetus clavis and Rodhocetus balochistanensis from Lakha Kach Rakhni areas were also reported [92].

\section{Conclusions and Recommendations}

Mari Bugti hills and surroundings revealed diverse lithostratigraphy, mostly alternated anticlines and synclines, marine and terrestrial environmental geological history, suitable structures for petroleum resources, vast and huge gypsum and cement resources demand urgent need for installation of cement industries, and other minerals like coal, celestite, construction materials, many suitable sites for water dam construction, biodiverse archosaurs especially distinguished titanosaurs and mesoeucrocodiles, pterosaur, bird and snake, and the largest land mammals.

Mari Bugti hills and surrounding areas need construction of small and medium sized dams (on Kaha, Chachar, Khargani, Belab, Karigari Poh, Khalgiri Zangy, Nilobar, Suki Ghazi, Bagga Khosra, Sakhi Bor Bakhsh (Bux), Bazi, Munni, Jhabar, Sori, Lehri, Kalani, Kahan, Bejhi, Mawand, Vitakri, and other major streams) and road connectivity for the development of agricultural resources, petroleum resources, vast cement and gypsum resources and other minerals and paleontological explorations which can play major role for the development of 
areas of Balochistan. The road connectivity needed from Dera Bugti to Loti to Giandari to Rojhan, Giandari to Rajanpur, Dera Bugti to Sham (Sham of Sardar Wadera Shero Bugti) to Kalchas to Lundi Saidan, Beaker to Sham to Giandari, Phailawagh to Beaker to Mat to Rakhni, Rakhni to Chacha to Chitri to Sakhi Bor Bux (Bakhsh), Lundi Saidan to Sakhi Bor Bux to Choti Bala, Vitakri to Makhmar, Vitakri to Beaker, Sibi to Kahan to Kohlu, Sibi to Mawand to Kohlu, Sibi to Mandai to Gamboli to Pazha, Kohlu to Gamboli, Gamboli to Spin Tangi, Pazha to Pur to Harnai, Sibi to Babar Kach to Spin Tangi to Harnai, Sibi to Badra to Sangan-e-Pain to Shahrig, Abegum to Marwar to Zardalu, Abegum to Sangan-e-Pain. Some roads are available but most of these need to be constructed for the development of natural resources.

\section{Acknowledgements}

This work is a contribution to the Geological Survey of Pakistan.

\section{Conflicts of Interest}

The authors declare no conflicts of interest regarding the publication of this paper.

\section{References}

[1] Jones, A.G., Manistere, B.E., Oliver, R.L., Willson, G.S. and Scott, H.S. (1961) Reconnaissance Geology of Part of West Pakistan. Colombo Plan Co-Operative Project Conducted and Compiled by Hunting Survey Corporation, Government of Canada, Toronto, $550 \mathrm{p}$.

[2] Fatmi, A.N. (1977) Mesozoic. In: Shah, S.M.I., Eds., Stratigraphy of Pakistan, Memoir, Vol. 12, Geological Survey of Pakistan, Quetta, 29-56.

[3] Cheema, M.R., Raza, S.M. and Ahmad, H. (1977) Cainozoic. In: Shah, S.M.I., Eds., Stratigraphy of Pakistan, Memoir, Vol. 12, Geological Survey of Pakistan, Quetta, 56-98.

[4] Shah, S.M.I. (2002) Lithostratigraphic Units of the Sulaiman and Kirthar Provinces, Pakistan. Geological Survey of Pakistan, Record, 107, 1-63.

[5] Kazmi, A.H. and Abbasi, I.A. (2008) Stratigraphy and Historical Geology of Pakistan. National Centre of Excellence in Geology, University of Peshawar, Peshawar, $524 \mathrm{p}$.

[6] Malkani, M.S. (2009) New Balochisaurus (Balochisauridae, Titanosauria, Sauropoda) and Vitakridrinda (Theropoda) Remains from Pakistan. Sindh University Research Journal (Science Series), 41, 65-92.

[7] Malkani, M.S. (2010) Updated Stratigraphy and Mineral Potential of Sulaiman (Middle Indus) Basin, Pakistan. Sindh University Research Journal (Science Series), 42, 39-66.

[8] Malkani, M.S. (2011) Stratigraphy, Mineral Potential, Geological History and Paleobiogeography of Balochistan Province, Pakistan. Sindh University Research Journal (Science Series), 43, 269-290.

[9] Malkani, M.S. and Mahmood, Z. (2016) Revised Stratigraphy of Pakistan. Geological Survey of Pakistan, Record, 127, 1-87.

[10] Malkani, M.S. and Mahmood Z. (2017) Stratigraphy of Pakistan. Geological Survey 
of Pakistan, Memoir, 24, 1-134.

[11] Malkani, M.S., Dhanotr, M.S.I. and Shakeel, A. (2007) Geological Map of Dera Bugti quadrangle, 39 G/4, Dera Bugti District, Balochistan, Pakistan. Geological Survey of Pakistan, Geological Map.

[12] Malkani, M.S. and Haq, M. (2000) Geology of Kohlu Area 39G/5, Kohlu and Barkhan Districts, Balochistan, Pakistan. Geological Survey of Pakistan, Information Release, 727. (Plus Geological Map of Quadr. on 1:50,000 Scale, Mapped by Malkani, M.S. and Haq, M.)

[13] Anwar, C.M. and Malkani, M.S. (2001) Geology of Vitakri Area 39 G/6, Barkhan, Kohlu and Dera Bugti Districts, Balochistan, Pakistan. Geological Survey of Pakistan, Information Release, 733. (Plus Geological Map of Quadrangle).

[14] Malkani, M.S. and Dhanotr M.S.I. (2007) Geological Map of Phailawagh Quadrangle, 39 G/7, Dera Bugti District, Balochistan, Pakistan. Geological Survey of Pakistan, Geological Map.

[15] Malkani, M.S. and Hussain, Z. (2001) Geological Map of Beaker Quadrangle, 39 G/10, Dera Bugti, Kohlu and Barkhan Districts, Balochistan. Geological Survey of Pakistan, Geological Map.

[16] Malkani, M.S., Hussain, Z., Dhanotr, M.S.I. and Shah, M.R. (2010) Geological Map of Fort Munro Quadrangle, 39G/13, Barkhan, Dera Ghazi Khan and Rajan Pur Districts of Balochistan and Punjab Provinces, Pakistan. Geological Survey of Pakistan, Geological Map.

[17] Malkani, M.S., Tariq, M. and Hussain, Z. (2002) Geological Map of Loralai Quadrangle, 39 B/11, Dera Bugti, Kohlu and Barkhan Districts, Balochistan, Pakistan. Geological Survey of Pakistan, Geological Map.

[18] Malkani, M.S., Haq, M. and Khan, S.H. (1997) Geological Map of Shabozai Area 39 B/15, Loralai District, Balochistan, Pakistan. Geological Survey of Pakistan, Geological Map.

[19] Tariq, M., Malkani, M.S., Haq, M. and Khan, S.H. (1997) Geological Map of Kotkai area 39 F/3, Loralai District, Balochistan, Pakistan. Geological Survey of Pakistan, Geological Map.

[20] Malkani, M.S. and Shahani, A.A. (2001) Geological Map of Hosri area 39 F/4, Loralai and Kohlu Districts, Balochistan, Pakistan. Geological Survey of Pakistan, Geological Map.

[21] Malkani, M.S., Tariq, M. and Haq, M. (1996) Geological Map of Mekhtar Quadrangle 39 F/7, Loralai District, Balochistan, Pakistan. Geological Survey of Pakistan, Geological Map.

[22] Malkani, M.S., Hussain, Z., Shah, M.R. and Dhanotr, M.S.I. (2010) Geological Map of Chamalang Quadrangle, 39F/8, Loralai, Barkhan and Kohlu Districts, Balochistan, Pakistan. Geological Survey of Pakistan. Geological Survey of Pakistan, Geological Map.

[23] Malkani, M.S., Hussain, Z., Shah, M.R. and Dhanotr, M.S.I. (2010) Geological Map of Bahlol Quadrangle, 39F/12, Barkhan, Musa Khel, Loralai and Kohlu Districts, Balochistan. Geological Survey of Pakistan, Geological Map.

[24] Haq, M. and Malkani, M.S. (1997) Geological Map of Musa Khel Bazar area 39F/13, Musa Khel District, Balochistan, Pakistan. Geological Survey of Pakistan, Geological Map.

[25] Malkani, M.S., Haq, M, Hussain, Z., Dhanotr, M.S.I. and Shah, M.R. (2007) Geological Map of Kingri Quadrangle 39 F/15, Musa Khel, and Dera Ghazi Khan Dis- 
tricts, Balochistan and Punjab Provinces, Pakistan. Geological Survey of Pakistan, Geological Map.

[26] Malkani, M.S. and Haq, M., (2000) Geology of Rakhni Area 39 F/16, Barkhan and D.G.Khan Districts, Balochistan and Punjab Provinces, Pakistan. Geological Survey of Pakistan, Information Release, 705, (Plus Geological Map of Quadrangle on 1: 50,000 Scale, Mapped by Malkani, M.S. and Haq, M.).

[27] Malkani, M.S., Hussain, Z., Shah, M.R. and Dhanotr, M.S.I. (2007) Geological Map of Toi Quadrangle, 39 I/4, Musa Khel and Dera Ghazi Khan Distt, Balochistan and SouthPunjab. Geological Survey of Pakistan, Geological Map.

[28] Malkani, M.S. (2012) Revised Lithostratigraphy of Sulaiman and Kirthar Basins, Pakistan. Journal of Himalayan Earth Sciences, 45, 72.

[29] Malkani, M.S. (2004) Stratigraphy and Economic Potential of Sulaiman, Kirthar and Makran-Siahan Ranges, Pakistan. 5th Pakistan Geological Congress, Islamabad, 14-15 April 2004, 63-66.

[30] Malkani, M.S., Mahmood, Z., Alyani, M.I. and Shaikh, S.I. (2017) Revised Stratigraphy and Mineral Resources of Sulaiman Basin, Pakistan. Information Release, No. 1003, Geological Survey of Pakistan, Quetta, 1-63.

[31] Malkani, M.S. (2019) Recently Discovered Basilosaurid, Baluchithere Rhinoceros, Horses, Sea Cow, Proboscidean, Eucrocodile, Pterosaurs, Plesiosaur, Fishes, Invertebrates and Wood Fossils, Tracks and Trackways of Dinosaurs from Pakistan; Comparison of Recognized Four Titanosaur Taxa of Indo-Pakistan with Madagascar. Open Journal of Geology, 9, 919-955. https://doi.org/10.4236/ojg.2019.912098

[32] Malkani, M.S. (2021) Formal Description of Mesozoic and Cenozoic Biotas Found from Pakistan. Open Journal of Geology, 11, 411-455. https://doi.org/10.4236/ojg.2021.119023

[33] Williams, M.D. (1959) Stratigraphy of the Lower Indus Basin, West Pakistan. World Petroleum Cong., 5th, New York, Proc. Sec, 1, 19, 277-394.

[34] Abbas, S.G., Kakepoto, A.A. and Ahmad, M.H. (1998) Iron Ore Deposits of Dilband Area, Mastung District, Kalat Division, Balochistan. Information Release No. 679, Geological Survey of Pakistan, Quetta, 1-19.

[35] Malkani, M.S. and M. Haq (1998) Discovery of Pegmatite and Associated Plug in Tor Ghundi Shabozai Area, Loralai District, Balochistan, Pakistan. Information Release No. 668, Geological Survey of Pakistan, Quetta, 1-19.

[36] Jadoon, I.A.K. and Baig, M.S. (1991) Tor Ghar, an Alkaline Intrusion in the Sulaiman Fold and Thrust System of Pakistan. Kashmir Journal of Geology, 8-9, 111-115.

[37] Malkani, M.S. (2003) First Jurassic Dinosaur Fossils Found from Kirthar Range, Khuzdar District, Balochistan, Pakistan. Geological Bulletin, University of Peshawar, 36, 73-83.

[38] Blanford, W.T. (1879) The Geology of Western Sind. Memoirs of the Geological Survey of India, 17, 1-196.

[39] Vredenburg, E.W. (1906) The Classification of the Tertiary System in Sind with Reference to the Zone Distribution of the Eocene Echinoidea Described by Duncan and Sladen. Records of the Geological Survey of India, 34, 172-198.

[40] Malkani, M.S. (2006) Lithofacies and Lateral Extension of Latest Cretaceous Dinosaur Beds from Sulaiman Foldbelt, Pakistan. Sindh University Research Journal (Science Series), 38, 1-32.

[41] Malkani, M.S. (2020) Pakisaurus balochistani (Poripuchia, Slender Titanosauria, Sauropoda) Associated Skeletons from the Latest Maastrichtian Vitakri Formation 
of Pakistan and Referred Fossils from India; Filling of Significant Missing Links of Isisaurus colberti (Poripuchia, Slender Titanosauria, Sauropoda) Found from Pakistan. Open Journal of Geology, 10, 408-447. https://doi.org/10.4236/ojg.2020.104019

[42] Malkani, M.S. (2021) Jurassic-Cretaceous and Cretaceous-Paleogene Transitions and Mesozoic Vertebrates from Pakistan. Open Journal of Geology, 11, 275-318. https://doi.org/10.4236/ojg.2021.118016

[43] Oldham, T. (1890) Proceedings of the Asiatic Society of Bengal for July, 1860. The Journal of the Asiatic Society of Bengal, 29, 318-319.

[44] Malkani, M.S. (2010) New Pakisaurus (Pakisauridae, Titanosauria, Sauropoda) Remains, and Cretaceous Tertiary (K-T) Boundary from Pakistan. Sindh University Research Journal (Science Series), 42, 39-64.

[45] Siddiqui, S, Jamiluddin, I.H., Qureshi and Kidwai, A.H. (1965) Geol. Map of Degree Sheet 39 J. Geological Survey of Pakistan, Quetta.

[46] Eames, F.E. (1951) A Contribution to the Study of the Eocene in West Pakistan and Western India; Part A, The Geology of Standard Sections in the Western Punjab and in the Kohat District. Part B, Description of the Fauna of Certain Standard Sections and Their Bearing on the Classification and Correlation of the Eocene in Western Pakistan and Western India. The Quarterly Journal of the Geological Society of London, 107, 159-171. https://doi.org/10.1144/GSL.JGS.1951.107.01-04.07

[47] Hemphill, W.R. and Kidwai, A.H. (1973) Stratigraphy of the Bannu and Dera Ismail Khan Areas, Pakistan. Paper No. 716 B, United States Geological Survey, Reston, 1-36. https://doi.org/10.3133/pp716B

[48] Khan, S.H. (2009) Geological Map of 39 G, Pakistan. Geological Survey of Pakistan, Quetta.

[49] Tainsh, H.R., Stringer, K.V. and Azad, J. (1959) Major Gas Fields of West Pakistan. AAPG Bulletin, 43, 2675-2700. https://doi.org/10.1306/0BDA5F3F-16BD-11D7-8645000102C1865D

[50] Malkani, M.S., Mahmood, Z., Shaikh, S.I. and Arif, S.J. (2017) Mineral Resources of Balochistan Province, Pakistan. Information Release No. 1001, Geological Survey of Pakistan, Quetta, 1-43.

[51] Malkani, M.S., Alyani, M.I., Khosa, M.H. Somro, N., Arif, S.J., Tariq, S., Saeed, F., Khan, G. and Faiz, J. (2016) Mineral Resources of Pakistan-An Update. Lasbela University Journal of Science \& Technology, 5, 90-114.

[52] Malkani, M.S. and Mahmood, Z. (2016) Mineral Resources of Pakistan: A Review. Geological Survey of Pakistan, Record, 128, 1-90.

[53] Malkani, M.S. and Mahmood, Z. (2017) Mineral Resources of Pakistan: Provinces and Basins Wise. Geological Survey of Pakistan, Memoir, 25, 1-179.

[54] Malkani, M.S. (2020) Cement Resources, Agrominerals, Construction, Marble, Dimension and Decor Stone Resources, Gemstone and Jewelry Resources of Pakistan. Open Journal of Geology, 10, 900-942. https://doi.org/10.4236/ojg.2020.108041

[55] Malkani, M.S., Mahmood, Z., Shaikh, S.I. and Alyani, M.I. (2017) Mineral Resources of North and South Punjab, Pakistan. Information Release No. 995, Geological Survey of Pakistan, Quetta, 1-52.

[56] Malkani, M.S. (2000) Preliminary Report on Gypsum Deposits of Sulaiman Range, Pak. Information Release No. 706, Geological Survey of Pakistan, Quetta, 1-11.

[57] Malkani, M.S. (2018) Cement Resources and Gypsum Deposits of Pakistan: Urgent Installation of Cement Industries in Daman of Sulaiman Range. Journal of Hima- 
layan Earth Sciences, 2018, 180.

[58] Malkani, M.S. (2012) A Review of Coal and Water Resources of Pakistan. Science, Technology and Development, 31, 202-218.

[59] Malkani, M.S., Alyani, M.I., Khosa, M.H. Buzdar, F.S. and Zahid, M.A. (2016) Coal Resources of Pakistan: New Coalfileds. Lasbela University Journal of Science and Technology, 5, 7-22.

[60] Malkani, M.S. and Mahmood, Z. (2017) Coal Resources of Pakistan: Entry of New Coalfields. Information Release No. 980, Geological Survey of Pakistan, Quetta, $1-28$.

[61] Malkani, M.S. (2018) Chamalang-Lunda-Nosham Coalfields of Balochistan, Pakistan: Foresight Strategy and Policy. Journal of Himalayan Earth Sciences, ESP 2018 , 26.

[62] Malkani, M.S. and Dhanotr, M.S.I. (2018) Kingri and Toi Nala (Ghoze Ghar-Savi Ragha) Coalfields of Musakhel District, Balochistan, Pakistan: Foresight Strategy. Journal of Himalayan Earth Sciences, ESP 2018, 21.

[63] Malkani, M.S. and Shah, M.R. (2014) Chamalang Coal Resources and Their Depositional Environments, Balochistan, Pakistan. Journal of Himalayan Earth Sciences, 47, 61-72.

[64] Malkani, M.S. (2012) Discovery of Fluorite Deposits from Loralai District, Balochistan, Pakistan. Journal of Himalayan Earth Sciences, 45, 69.

[65] Malkani, M.S., Alyani, M.I. and Khosa, M.H. (2016) New Fluorite and Celestite deposits from Pakistan: Tectonic and Sedimentary Mineral Resources of Indus Basin (Pakistan)-An Overview. Lasbela University Journal of Science and Technology, 5, 27-33.

[66] Malkani, M.S. and Mahmood, Z. (2017) Fluorite from Loralai-Mekhtar and Celestite from Barkhan, Dera Bugti, Kohlu, Loralai and Musakhel Districts (Sulaiman Foldbelt) and Karkh Area of Khuzdar District (Kirthar Range): A Glimpse on Tectonic and Sedimentary Mineral Resources of Indus Basin (Pakistan). Information Release No. 981, Geological Survey of Pakistan, Quetta, 1-16.

[67] Malkani, M.S. (2012) Discovery of Celestite Deposits in the Sulaiman (Middle Indus) Basin, Balochistan, Pakistan. Journal of Himalayan Earth Sciences, 45, 68-69.

[68] Malkani, M.S. and Mahmood, Z. (2016) Clay (Ceramic) Mineral Resources of Pakistan: Recent Advances in Discoveries. Journal of Himalayan Earth Sciences, ESP 2016, 101 .

[69] Malkani, M.S. and Tariq, M. (2000) Barite Mineralization in Mekhtar Area, Loralai District, Balochistan, Pakistan. Information Release No. 672, Geological Survey of Pakistan, Quetta, 1-9.

[70] Malkani, M.S., Qazi, S., Mahmood, Z., Khosa, M.H., Shah, M.R., Pasha, A.R. and Alyani, M.I. (2016) Agromineral Resources of Pakistan: An Urgent Need for Further Sustainable Development. Journal of Himalayan Earth Sciences, ESP 2016, 51-52.

[71] Malkani, M.S., Qazi, S., Khosa, M.H., Shah, M.R., Zafar, T. and Arif, J. (2018) Iron, Laterite, Bauxite and Ochre Deposits of Pakistan: Emphasis on Feasible Dilband and Low Grade Fort Munro Ironstones. Journal of Himalayan Earth Sciences, ESP 2016, 178-179.

[72] Malkani, M.S., Qazi, S., Khosa, M.H., Shah, M.R., Zafar, T. and Arif J. (2018) Industrial Mineral Deposits of Pakistan: Significant for Sustainable Development of Pakistan. Journal of Himalayan Earth Sciences, ESP 2018, 175-176. 
[73] Malkani, M.S., Qazi, S., Shah, M.R. and Zafar, T. (2018) Sandstone Type Uranium Resources of Pakistan: Encouraging Huge Strata. Journal of Himalayan Earth Sciences, ESP 2018, 167.

[74] Malkani, M.S. (2015) Dinosaurs, Mesoeucrocodiles, Pterosaurs, New Fauna and Flora from Pakistan. Information Release No. 823, Geological Survey of Pakistan, Quetta, 1-32.

[75] Sahni, A. (2001) Dinosaurs of India. National Book Trust, Delhi, 110 p.

[76] Malkani, M.S. (2020) First Skull of Medium Sized Titanosaur from Indo-Pakistan Subcontinent Found from Found from the Latest Maastrichtian Vitakri Formation of Pakistan; Associated Cranial and Postcranial Skeletons of Gspsaurus pakistani (Poripuchia, Stocky Titanosauria, Sauropoda) from Pakistan and India. Open Journal of Geology, 10, 448-489. https://doi.org/10.4236/ojg.2020.104020

[77] Malkani, M.S. (2020) First Snout with Complete Teeth Row of Titanosaur from Indo-Pakistan Subcontinent Found from the Latest Maastrichtian Vitakri Formation of Pakistan; Associated Cranial and Postcranial Skeletons of Saraikimasoom vitakri (Poripuchia, Stocky Titanosauria, Sauropoda) from Pakistan and Referred Fossils from India. Open Journal of Geology, 10, 368-407. https://doi.org/10.4236/ojg.2020.105023

[78] Malkani, M.S. (2020) Theropods, Mesoeucrocodiles and Pterosaurs Found from the Latest Maastrichtian Vitakri Formation of Balochistan, Pakistan; Description with Large Photographs and Comparison with Coeval Taxa from Indo-Pakistan Subcontinent. Open Journal of Geology, 10, 510-551.

https://doi.org/10.4236/ojg.2020.105023

[79] Malkani M.S. (2021) Titanosaurs from India and Pakistan; Cretaceous Archosaurs from Pakistan. 2nd International Symposium of International Geoscience Program Project IGCP 679 "Cretaceous Earth Dynamics and Climate in Asia”, Online Meeting, Nanjing, 26-27 October 2021, 9-12.

[80] Malkani, M.S. (2003) Pakistani Titanosauria; Are Armoured Dinosaurs? Geological Bulletin University of Peshawar, 36, 85-91.

[81] Malkani, M.S. (2008) Marisaurus (Balochisauridae, Titanosauria) Remains from the Latest Cretaceous of Pakistan. Sindh University Research Journal (Science Series), 40, 55-78.

[82] Malkani, M.S. (2010) Osteoderms of Pakisauridae and Balochisauridae (Titanosauria, Sauropoda, Dinosauria) in Pakistan. Journal of Earth Science, 21, 198-203. https://doi.org/10.1007/s12583-010-0212-Z

[83] Malkani, M.S., Somro, N. and Arif, S.J. (2018) A New Pes Footprint of Sauropod Dinosaur Discovered from the Latest Cretaceous of Pakistan. Researchgate.net, Research, $1 \mathrm{p}$.

[84] Malkani, M.S. (2007) Trackways Evidence of Sauropod Dinosaurs Confronted by a Theropod Found from Middle Jurassic Samana Suk Limestone of Pakistan. Sindh University Research Journal (Science Series), 39, 1-14.

[85] Vicary, N. (1846) Geological Report on a Portion of the Baluchistan Hills. Geol. Soc. London Quaternary Journal of London, 2, 260-267. https://doi.org/10.1144/GSL.JGS.1846.002.01-02.44

[86] Cooper, C.F. (1924) On the Skull and Dentition of Paraceratherium Bugtiensis a Genus of Aberrant Rhinoceroses from the Lower Miocene of Dera Bugti. Philosophical Transactions of the Royal Society B, 212, 369-394. https://doi.org/10.1098/rstb.1924.0009

[87] Pilgrim, G.E. (1908) The Tertiary and Post Tertiary Fresh Water Deposits of Balu- 
chistan and Sind, with Notices of New Vertebrates. Geological Survey of India, Records, 37, 139-166.

[88] Cooper, C.F. (1911) Paraceratherium bugtiensis, a New Genus of Rhinoceratidae from Bugti Hills of Balochistan. Memoirs of the Geological Survey of India, 40, 1-65.

[89] Shah, S.M.I. and Arif, M. (1992) A Description of a Skull and Mandible of Bugtitherium grandincivism of the Bugti Hills. Memoirs of the Geological Survey of India, 17, 29-40.

[90] Raza, S.M. and Meyer, G.E. (1984) Early Miocene Geology and Paleontology of the Bugti Hills. Geological Survey of Pakistan, Memoir, 11, 43-63.

[91] Malkani, M.S., Dhanotr, M.S.I., Latif, A. and Saeed, H.M. (2013) New Remains of Basilosauridae-The Giant Basal Whale, and Baluchithere-The Giant Rhinoceros Discovered from Balochistan Province (Pakistan). Sindh University Research Journal (Science Series), 45, 177-188.

[92] Gingerich, P.D., Haq, M.U., Zalmout, I.S., Khan, I.H. and Malkani, M.S. (2001) Origin of Whales from Early Artiodactyls: Hands and Feet of Eocene Protocetidae from Pakistan. Science, 293, 2239-2242. https://doi.org/10.1126/science.1063902 